УДК 573.3

Yu. M. Yevdokimov' ${ }^{I}$, S. G. Skuridin ${ }^{1}$, V. I. Salyanov ${ }^{I}$, E. R. Muzipov ${ }^{2}$, S. V. Semenov ${ }^{3}$, E. I. Kats ${ }^{4}$

\title{
DOUBLE-STRANDED DNA PACKING IN PARTICLES OF LIQUID-CRYSTALLINE DISPERSIONS AND LIQUID-CRYSTALLINE PHASES OBTAINED FROM THESE PARTICLES
}

\author{
${ }^{1}$ Engelhardt Institute of Molecular Biology of the Russian Academy of Sciences, \\ 32 Vavilova St., Moscow, 119991 Russia. E-mail: yevdokim@eimb.ru \\ ${ }^{2}$ Limited Liability Company «D-Micro», 74 Flotskaya St., Moscow, 125413, Russia. \\ ${ }^{3}$ National Research Centre «Kurchatov Institute», 1 Kurchatov square, Moscow, 123182, Russia. \\ ${ }^{4}$ Landau Institute for Theoretical Physics of the Russian Academy of Sciences, \\ 2 Kosygina St., Moscow, 119334, Russia
}

In this research we compared the optical properties of liquid-crystalline DNA dispersion particles formed as a result of the phase exclusion of double-stranded (ds) DNA molecules from aqueous-salt of poly(ethylene glycol) solutions and the phases obtained from these dispersions. It is shown that the liquid-crystalline dispersions with cholesteric packing of double-stranded DNA molecules are characterized by an intense (abnormal) negative band in the circular dichroism (CD) spectrum. The phases obtained from these dispersions possess "fingerprint» texture at both room and elevated temperatures. The CD spectra without abnormal band are found for double-stranded DNA dispersions with an initial hexagonal packing of molecules, which are formed at room temperatures. However, the temperature increase results in the appearance of an abnormal band in the $C D$ spectrum of the hexagonal double-stranded DNA dispersion particles. The observed optical effect corresponds to a new "hexagonal $\rightarrow$ re-entrant cholesteric" phase transition in the case of the particles formed by both the semi-rigid and flexible ds DNA molecules. Unlike the dispersion particles, the textures of phases obtained from these particles do not demonstrate any attributes typical of conventional cholesterics. These textures present anisotropic domains with beautiful colors at room and elevated temperatures. In the agreement with the measured magnitude of the abnormal CD band, the colors can reveal a very small helical pitch well below the values known for classical cholesterics.

Key words: liquid-crystalline ds DNA dispersion particles, circular dichroism, abnormal optical activity, textures, hexagonal packing of ds DNA molecules in dispersion particles, cholesteric packing of ds DNA molecules in dispersion particles, hexagonal $\rightarrow$ cholesteric phase transition.

DOI: $10.18083 /$ LCAppl.2018.2.64

(C) Yevdokimov Yu. M., Skuridin S. G., Salyanov V. I., Muzipov E. R., Semenov S. V., Kats E. I., 2018 


\title{
Ю. М. Евдокимов ${ }^{1}$ С. Г. Скуридин ${ }^{1}$, В. И. Салянов ${ }^{1}$, Э. Р. Музипов ${ }^{2}$, С. В. Семёнов ${ }^{3}$, Е. И. Кац
}

\section{УПАКОВКА ДВУХЦЕПОЧЕЧНЫХ МОЛЕКУЛ ДНК В ЧАСТИЦАХ ЖИДКОКРИСТАЛЛИЧЕСКИХ ДИСПЕРСИЙ И ЖИДКОКРИСТАЛЛИЧЕСКИХ ФАЗАХ, СФОРМИРОВАННЫХ ИЗ ЭТИХ ЧАСТИЦ}

\author{
${ }^{1}$ Институт молекулярной биологии им. В. А. Энгельгардта РАН, \\ ул. Вавилова, 32, 119991 Москва, Россия. E-mail: yevdokim@eimb.ru \\ ${ }^{2}$ ООО «Д-Микро», Флотская ул., 74, 125413 Москва, Россия, \\ ${ }^{3}$ Национальный исследовательский центр «Курчатовский институт», \\ пл. акад. Курчатова, 1, 123182 Москва, Россия \\ ${ }^{4}$ Институт теоретической физики им. Л. Д. Ландау РАН \\ ул. Косыгина, 2, 119334 Москва, Россия
}

Проведено сравнительное изучение оптических свойств частии ЖК-дисперсий и ЖК-фаз ДНК. Частииы ЖК-дисперсий с холестерическим способом упаковки молекул ДНК обладают аномальной отрииательной полосой в спектре кругового дихроизма (КД), а фазы ДНК, полученные на основе этих частии - текстурой «отпечатков пальцев» в иироком интервале температур (от 22 до $80{ }^{\circ} \mathrm{C}$ ). B спектрах КД частии ЖК дисперсий с гексагональной упаковкой молекул ДНК аномальная полоса отсутствует. Однако повышение температуры сопровождается появлением в их КД спектрах аномальной полосы. Наблюдаемый оптический эффект соответствует фазовому переходу «гексагональная $\rightarrow$ возвратная холестерическая фаза» в случае частии, образованных как из жестких, так и из гибких двухиепочечных молекул ДНК. Однако текстуры фаз, сформированные на основе этих частии, не содержат признаки, характерные для холестериков. Текстуры этих фаз при разных температурах представляют собой многоцветные анизотропные домены. Не исключено, что $в$ соответствии с данными спектроскопии кругового дихроизма наличие таких текстур показывает, что шаг пространственной спиральной закрутки образуемых в этих условиях холестериков значительно меньше шага, характерного для классических холестериков двухиепочечных молекул ДНК.

Ключевые слова: частищы жидкокристаллических дисперсий двухцепочечной ДНК, круговой дихроизм, аномальная оптическая активность, текстуры, гексагональная упаковка двухцепочечных молекул ДНК в частищах дисперсий, холестерическая упаковка двухиепочечных молекул ДНК в частицах дисперсий, фазовый переход гексагональная $\rightarrow$ холестерическая фаза.

\section{Introduction}

The packing of double-stranded (ds) DNA molecules in liquid-crystalline (LC) phases is still in a focus of many experimental and theoretical works (see, e.g. [1-6]). The X-ray diffraction parameters, the thin layer textures and electron microscopy photographs of the phases made it possible to establish the details of the ds DNA packing in the formed LC phases. The cascade of phases established in these works looks as follows: isotropic phase $\rightarrow$ (blue phase?) $\rightarrow$ cholesteric phase $\rightarrow$ columnar phase $\rightarrow$ crystalline phase [7-12].

As a rule, ds DNA LC phases were obtained by dissolution of lyophilized ds DNA samples (of high and low molecular mass) in a very small amount of buffer (with an adjustment the concentration with the added a buffer solution).

It is known as well that, at room temperature, along with the LC phases, the ds DNA liquidcrystalline dispersion (LCD) particles can be formed $[13,14]$. The dispersions can be obtained by the phase exclusion (condensation) of linear ds DNA molecules from aqueous-salt-poly(ethyleneglycol) (PEG) solutions $[15,16]$ or mixtures of PEG with a mineral oil [17]. This process, depending on the molecular mass of ds DNA molecules, is realized as the intramolecular or the intermolecular assembling of molecules [6-18] into the dispersion particles, driven by packing constrains and enforced by the van der Waals, hydrophobic and electrostatic interactions. Note that the particles of the low molecular mass ds 
DNA dispersions are "microscopic droplets of concentrated DNA solution". The LCD particles in their "liquid-like" state exist only above some "critical" osmotic pressure of the solution [6]. A "liquid-like" packing ds DNA molecules in the dispersion particles prevents their immobilization on the surface of membrane filters.

Theoretical estimations of the ds DNA LCD particle size, based on the data obtained by different methods (low-speed centrifugation, UV-light scattering, dynamic light scattering, etc.), show, that for the DNA with molecular mass about $(0.6-0.8) \times 10^{6}$ Da the mean particle diameter is close to $500 \mathrm{~nm}$, and one particle contains about $10^{4}$ DNA molecules [19]. These results were confirmed by the direct atomic force microscopy data on the specially prepared "rigid" (gel-like) ds DNA dispersion particles, immobilized on the surface of nuclear membrane filters [20].

According to the estimates, the mean size of dispersion particle depends on: (i) the ds DNA concentration, and (ii) the PEG concentration (i.e., osmotic pressure) needed for the phase exclusion $[6,16,21]$.

There is limited number of simple methods which enable identify basic structural and physical properties of LC phases and LCDs. For instance, the polarizing microscope allows to observe the specific optical pattern (texture) of a thin layer of LC phase. The texture is determined by macroscopic orientation of molecules (or molecular layers) in the sample; it helps to determine the molecular structure of LC phase. In the case of a cholesteric liquid crystals, the quasinematic layers formed by molecules are regularly twisted in space, giving rise to a helical structure in which the molecules are all perpendicular to the helicoidal axis. Between crossed polars the cholesteric phase usually shows periodic alterations of light and dark lines (it is a well-known "fingerprint texture"). Hence, polarizing microscope can be used to identify structural features of LC phase.

A very useful and robust global information about the mode of ds DNA molecules packing within spatially distributed, independent, small size dispersion particles can be obtained by application of circular dichroism (CD) method [22,23]. The "molecular circular dichroism" (expressed as $\Delta \varepsilon$ value, $\Delta \varepsilon \sim 2.5 \mathrm{M}^{-1} \mathrm{~cm}^{-1}$ ), i.e. the physical constant is usually used for description of the peculiarities of isolated nitrogen bases or individual DNA molecules.
The value of $\Delta \varepsilon$ can be calculated theoretically [24]. On the other hand, in the case of DNA LC phase with the cholesteric packing of molecules, the theoretical studies [25-28] predict an appearance of an intense band in the CD spectrum located in the region of absorption of the chromophores introduced in this phase. After B. Norden paper [29] this band is expressed as $\Delta \mathrm{A}$ (in optical units) and reflects a socalled "structural circular dichroism". Its value is related mainly to the spatial parameters of LCD particles (their diameter (D) and the magnitude of the cholesteric pitch $(\mathrm{P}))$. Hence, proof of the specific mode of ds DNA molecule packing in dispersion particles can be based on an analysis of their CD spectra peculiarities $[6,23]$. In order to stress the difference between the "molecular circular dichroism" and the "structural circular dichroism" we utilized the term "abnormal band" for an intense band in the CD spectrum [30].

The study of the ds DNA LCD particles has proven the existence (at room temperatures) of the following sequence of phase transitions: isotropic $\rightarrow$ cholesteric $\rightarrow$ hexagonal state driven by an increase of the PEG concentration in a solution [6].

In the recent publications of our group [31-33] we found that the ds DNA hexagonal phase, being optically inactive, is transformed upon heating to a new optically active phase, which was termed "reentrant cholesteric phase". After the time of writing the papers $[32,33]$ it seems fair to state that things have turned out to be considerably more complicated (and more interesting) than expected.

In what follows in this paper, we compared the structural circular dichroism (CD) spectra of the LCD particles formed by ds DNA molecules and thin layer textures of phases obtained from these particles, aiming to answer two questions.

1. Whether linear ds DNA's, which differ by molecular mass, form the dispersion particles capable of the "re-entrant cholesteric phase" transition?

2. Whether the "re-entrant cholesteric phase" can be identified by thin-layer textures?

The answer to these questions is important, because the physicochemical properties of the dispersion particles may be significantly different.

In addition, the properties of the ds DNA dispersion particles are interesting in own turn because these particles allow one to get insight on the characteristic features of the DNA packing in viruses or chromosomes of Protozoa, which are in fact dispersed 
microsystems with somehow ordered but mobile DNA molecules packing $[2,34]$.

\section{Experimental \\ 2.1. Preparation of ds DNA liquid-crystalline dispersions}

We have used several ds DNA preparations (calf thymus ("Sigma", USA); erythrocytes chicken blood ("Reanal", Hungary); salmon sperm (Russia) after additional purification and ultrasonic depolymerization. The mean molecular mass of the obtained ds DNA samples was determined by electrophoresis in a $1 \%$ agarose gel. The samples were divided into three groups: a) with a molecular mass of $\sim 13 \times 10^{6} \mathrm{Da}\left(\mathbf{M}_{1}\right)$; b) with the molecular mass of $\sim(0.5-0.8) \times 10^{6} \mathrm{Da}\left(\mathbf{M}_{2}\right)$; c) with the molecular mass of $\sim(0.2-0.3) \times 10^{6} \mathrm{Da}\left(\mathbf{M}_{3}\right)$.

The concentration of DNA in the aqueous salt solutions was determined using the known value of the molar extinction coefficient $\left(6,600 \mathrm{M}^{-1} \mathrm{~cm}^{-1}\right)$.

Poly(ethylene glycol) ("Serva", Germany) sample with a molecular mass of 4,000 Da was used without additional purification.

Initial aqueous salt solution of PEG $(0.3 \mathrm{M}$ $\mathrm{NaCl}, \mathrm{C}_{\mathrm{PEG}}=600 \mathrm{mg} \mathrm{ml}^{-1}$ ) was prepared by dissolving the weighed portions of $\mathrm{NaCl}$ and $\mathrm{PEG}$ in $0.002 \mathrm{M}$ $\mathrm{Na}^{+}$-phosphate buffer $(\mathrm{pH} \sim 7.0)$.

Double-stranded DNA dispersions in aqueoussalt solutions with different PEG concentrations $\left(120 \mathrm{mg} \mathrm{ml}^{-1} \leq \mathrm{C}_{\mathrm{PEG}} \leq 300 \mathrm{mg} \mathrm{ml}^{-1}\right)$ were prepared according to the phase exclusion (condensation) technology described previously [15]. According to this method, equal volumes of aqueous salt solutions, one of which contained DNA, and the other - PEG (concentration of DNA and PEG solution were twice higher than the desired final value) were mixed, and intensively stirred during $1 \mathrm{~min}$. The resulting mixture was allowed to leave at room temperature for $24 \mathrm{~h}$ to complete the formation of the DNA dispersion and then used in the work.

The DNA concentration in the studied PEGcontaining solutions was $10-30 \mu \mathrm{g} \mathrm{ml}^{-1}$.

\subsection{Optical measurements}

The ultraviolet absorption and circular dichroism (CD) spectra were recorded with Cary 100 Scan spectrophotometer ("Varian", USA) and with
SCD-2 portable dichrometer (produced by Institute of Spectroscopy of the Russian Academy of Sciences, Troizk, Moscow), respectively. The $\mathrm{CD}$ results are reported as $\Delta \mathrm{A}=\mathrm{A}_{\mathrm{L}}-\mathrm{A}_{\mathrm{R}}, \Delta \mathrm{A}$ being the difference in absorption between left and right polarized light at wavelength $\lambda[22]$.

In all cases the rectangular quartz cells ("Hellma" 100 QS, Germany) with a pathlength of $1 \mathrm{~cm}$ were used.

The temperature in the temperature-controlled compartment of dichrometer in the range of $20^{\circ} \mathrm{C}$ to $80{ }^{\circ} \mathrm{C}$ was set by the program "Temperature control", which is part of the software of the device. After setting the required temperature, a cell containing $2 \mathrm{ml}$ of DNA dispersion was heated for $10 \mathrm{~min}$ in a temperature controlled compartment, and the registration of the $\mathrm{CD}$ spectrum in the wavelength range of 250-350 $\mathrm{nm}$ was processed.

\subsection{Polarizing microscopy of ds DNA LC phases}

For polarizing microscopy the pellets $(\sim 2-$ $5 \mathrm{mg}$ ) of the ds DNA phases obtained by low-speed sedimentation $\left(5,000\right.$ rev. $\min ^{-1}, 40 \mathrm{~min}, 4{ }^{\circ} \mathrm{C}$; centrifuge K-23, Germany) of solutions containing ds DNA dispersion particles were used. These particles were formed as a result of DNA molecules phase exclusion $\left(\mathrm{C}_{\mathrm{DNA}}=30 \mu \mathrm{g} \mathrm{ml}^{-1}\right)$ in PEG-containing solutions (PEG concentrations is within $170 \mathrm{mg} \mathrm{ml}^{-1} \leq \mathrm{C}_{\mathrm{PEG}} \leq 300 \mathrm{mg} \mathrm{ml}^{-1}$ ).

To investigate the textures of ds DNA phases the special cell with stationary value of a sample thickness was used. To obtain this cell, on the surface (A) a quartz cylinder (diameter is $28 \mathrm{~mm}$, height is $4 \mathrm{~mm}$ ), a round layer by the depth $20 \mu \mathrm{m}$ (diameter is $20 \mathrm{~mm}$ ) was engraved and the flat surface $\mathbf{B}$ was formed. Around surface $\mathbf{B}$ a circular canal (depth is $2 \mathrm{~mm}$ ) capable (if necessary!) to take an excess of solution was created.

A very small piece of pellet, which represents a condensed ds DNA phase with a minor volume of PEG-containing supernatant, was deposited onto central part of surface B. Then the surface A was covered by quartz coverslip C (diameter $28 \mathrm{~mm}$, height $0.1 \mathrm{~mm}$ ), and it invoked the "compressing" of LC phase. As a result, ds DNA phase was spread on surface $\mathbf{B}$ and an excess of solution was accepted by circular canal. Hence, between surface $\mathbf{C}$ and surface B was formed the optical cell with constant sample thickness $(20 \mu \mathrm{m})$. This cell contained the sample of 
ds DNA phase. Additional teflon rings below quartz cylinder and on the surface $\mathbf{C}$ protect the ds DNA phase from evaporation. All construction was seated in thermostated holder with adjustable temperature.

The ds DNA phases were observed between crossed polars $(\times 40)$ in a $\mathrm{CX} 40 \mathrm{P}$ polarizing microscope ("Sunny Instruments", China).

\section{Results \\ 3.1. The CD spectra of ds DNA dispersions under various conditions}

A CD spectrum typical of classical linear ds DNA B-form (isotropic state of DNA, domain I) is well-known [24] and we do not plot this spectrum in Fig. 1, $A$.

The phase exclusion of ds DNA molecules with the "standard" molecular mass from aqueous-salt-PEG solutions $\left(\mathrm{C}_{\mathrm{PEG}}\right.$ from $120 \mathrm{mg} \mathrm{ml}^{-1}$ to $220 \mathrm{mg} \mathrm{ml}^{-1}$ or
PEG osmotic pressure from 2.062 to 9.001 atm, domain II in Fig. 1, B) [32] is accompanied usually by formation of dispersions which possess an abnormal (very intense) band in the CD spectrum located in the absorption range of DNA chromophores (Fig. 1, $A$, curves 1-4). This abnormal band reflects the mode of ds DNA molecule packing in individual dispersion particles (a so-called "structural circular dichroism") $[22,30]$. The appearance of this band in the CD spectrum in the absorption region of DNA chromophores (nitrogen bases) is (according to the theory [23]) the direct evidence of the formation of the helically twisted spatial (cholesteric) structure of ds DNA dispersion particles [26, 35].

The CD spectra without any abnormal band are typical of dispersions which are obtained at ds DNA phase exclusion under osmotic pressure of PEG greater than $9 \mathrm{~atm}$ (PEG concentrations is greater than $220 \mathrm{mg} \mathrm{ml}^{-1}$, domain III, Fig. 1, B) [32].
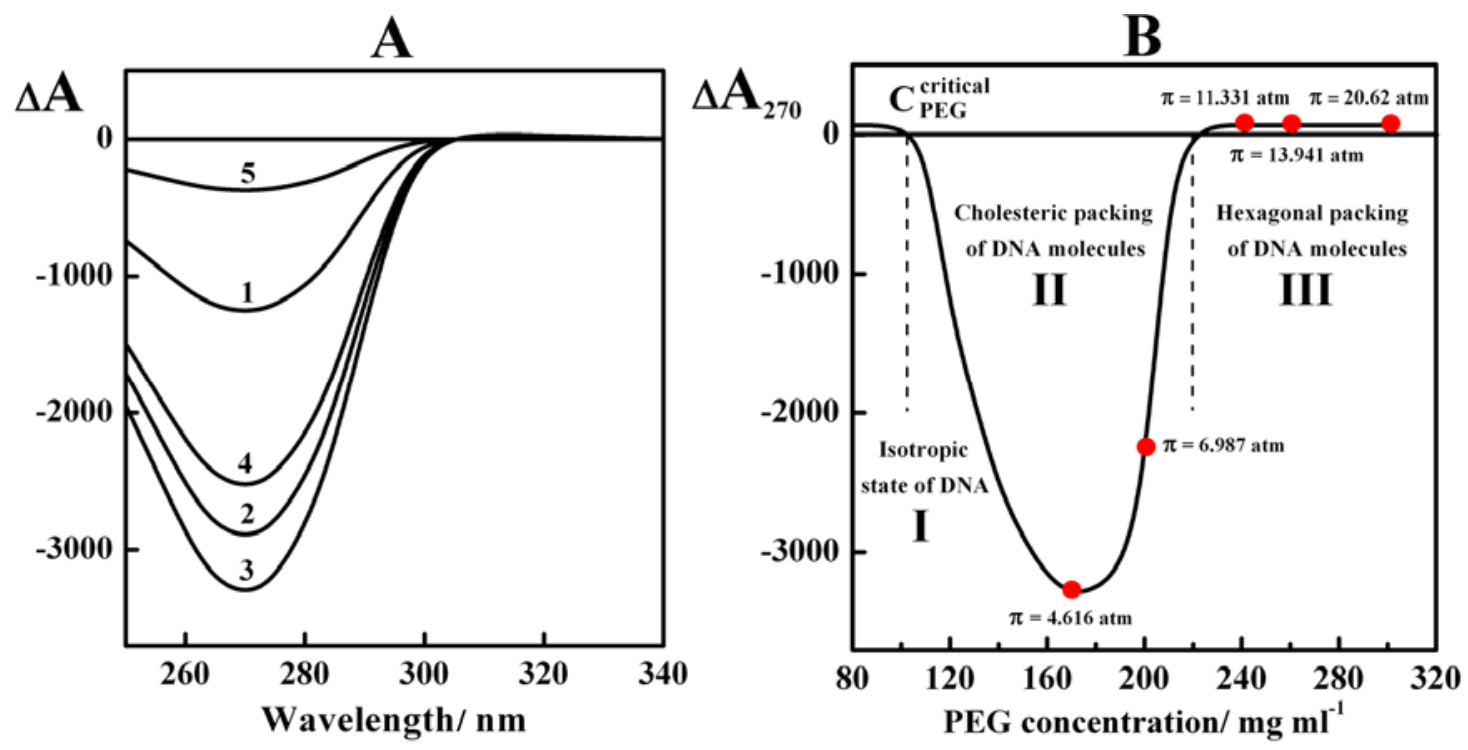

Puc. 1. A - The CD spectra of the DNA LCDs formed in aqueous salt solutions with different PEG concentration.

$1-\mathrm{C}_{\mathrm{PEG}}=120 \mathrm{mg} \mathrm{ml}^{-1}(\pi=2.062 \mathrm{~atm}), 2-\mathrm{C}_{\mathrm{PEG}}=150 \mathrm{mg} \mathrm{ml}^{-1}(\pi=3.422 \mathrm{~atm}), 3-\mathrm{C}_{\mathrm{PEG}}=170 \mathrm{mg} \mathrm{ml}^{-1}(\pi=4.616 \mathrm{~atm})$, $4-\mathrm{C}_{\mathrm{PEG}}=200 \mathrm{mg} \mathrm{ml}^{-1}(\pi=6.987 \mathrm{~atm}), 5-\mathrm{C}_{\mathrm{PEG}}=210 \mathrm{mg} \mathrm{m}^{-1}(\pi=7.839 \mathrm{~atm}) . \mathrm{C}_{\mathrm{DNA}}=10 \mu \mathrm{g} \mathrm{m}{ }^{-1} ; 0.3 \mathrm{M} \mathrm{NaCl}+0.002 \mathrm{M}$ $\mathrm{Na}^{+}$-phosphate buffer. $\Delta \mathrm{A}=\left(\mathrm{A}_{\mathrm{L}}-\mathrm{A}_{\mathrm{R}}\right) \times 10^{-6}$ optical units; $\mathrm{L}=1 \mathrm{~cm} ; \mathrm{T}=22^{\circ} \mathrm{C}$.

$\mathbf{B}$ - The generalized dependence of the amplitude of the band in the CD spectra of DNA LCDs $(\lambda=270 \mathrm{~nm})$ upon PEG concentration.

$\mathrm{C}_{\mathrm{DNA}}=10 \mu \mathrm{g} \mathrm{ml}^{-1} ; \quad 0.3 \mathrm{M} \mathrm{NaCl}+0.002 \mathrm{M} \mathrm{Na}^{+}$-phosphate buffer. $\quad \Delta \mathrm{A}_{270} \times 10^{-6}$ optical units; $\mathrm{L}=1 \mathrm{~cm} ; \mathrm{T}=22{ }^{\circ} \mathrm{C}$.

$\mathrm{C}_{\mathrm{PEG}}{ }^{\text {critical }}$ - "critical" concentration of PEG at which the formation of DNA LCDs begins. $\pi$ - osmotic pressure of PEG solution. Domain I - isotropic ds DNA solution; domain II and domain III - the existence of the ds DNA LCDs with cholesteric and hexagonal packing of molecules in particles, respectively 
It is worth to remind that the small-angle X-ray scattering data of the phases that were formed as a result of the low-speed sedimentation of the ds DNA dispersion particles under different PEG concentrations demonstrate the close dense packing of the ds DNA molecules in dispersion formed in the domains II and III [32].

In the domain II $\left(120 \mathrm{mg} \mathrm{ml}^{-1} \leq \mathrm{C}_{\mathrm{PEG}} \leq\right.$ $220 \mathrm{mg} \mathrm{ml}^{-1}$ ) the mean distance (d) between ds DNA molecules changes from $3.8 \mathrm{~nm}$ to $2.8 \mathrm{~nm}$; whereas in the domain III $\left(220 \mathrm{mg} \mathrm{ml}^{-1} \leq \mathrm{C}_{\mathrm{PEG}} \leq 320 \mathrm{mg} \mathrm{ml}^{-1}\right)$, the d value only slightly decreases (from 2.8 to $2.4 \mathrm{~nm})$ [32].

Therefore, in the domain II, the LCD particles formed by ds DNA molecules at room temperature possess a structure not only with the dense packing of the linear neighboring ds DNA molecules but also with the spatially twisted packing of these molecules. The ds DNA molecules spatial ordering in the LCD particles in the domain III is significantly different from that of in the domain II, and can be described as the hexagonal packing with the parallel (nematic like) alignment of the orientationally ordered ds DNA quasinematic layers [32].

Hence, the absence of an intense band in the CD spectra of dispersions formed in domain III points to the hexagonal packing of the ds DNA molecules.

Thus, the phase exclusion of the ds DNA mole- cules at room temperature leads to the formation of two main types of the dispersion particles depending on the osmotic pressure of PEG solution, i.e. cholesteric LC particles and hexagonal particles.

Fig. 1, $B$ clearly shows that that at room temperature there is the following sequence of ds DNA phase transitions: isotropic (I) $\rightarrow$ cholesteric (II) $\rightarrow$ hexagonal state (III) governed by an increase of the PEG concentration in a solution (PEG osmotic pressure).

We have tested the peculiarities of the CD spectra (at various temperatures) of ds DNA dispersions of different origin under PEG concentrations marked by red points in Fig. 1, $B$.

\subsection{Dispersion particles obtained from high molecular mass ds DNA molecules}

In Fig. 2 the CD spectra of dispersions obtained from ds DNA with molecular mass $\mathbf{M}_{\mathbf{1}}$ in the aqueoussalt solutions under conditions, which correspond to domain II $\left(\mathrm{C}_{\mathrm{PEG}}=170 \mathrm{mg} \mathrm{ml}^{-1}\right.$, Fig. $\left.1, B\right)$ and domain III $\left(\mathrm{C}_{\mathrm{PEG}}=240 \mathrm{mg} \mathrm{ml}^{-1}\right.$, Fig. $\left.1, B\right)$ at room and elevated temperatures, are compared. Long ds DNA molecules can be easily excluded from aqueous salt PEG-containing solutions because their length exceeds by far the DNA persistence length and they can therefore fold back on itself.
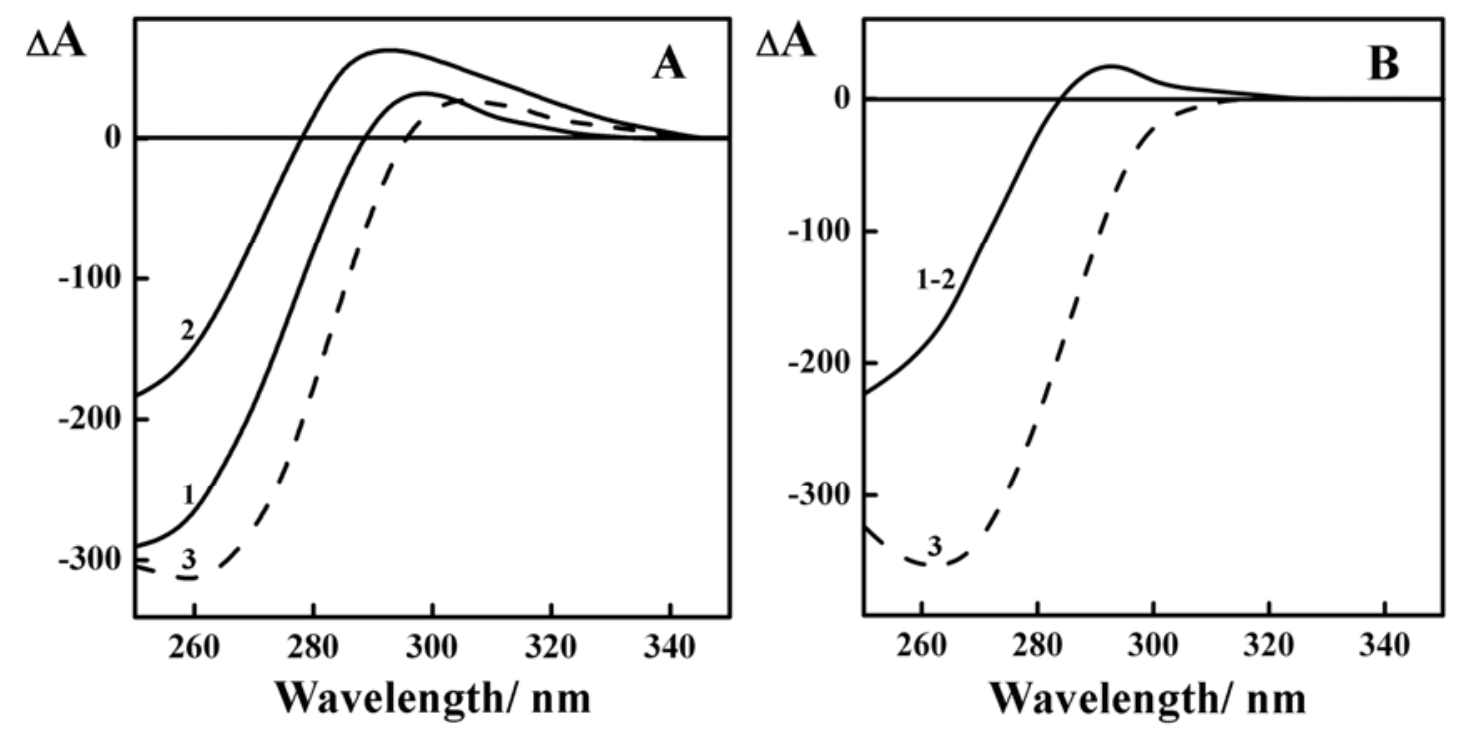

Fig. 2. The CD spectra of the LCDs obtained from high molecular mass ds DNA molecules in PEG-containing aqueous-salt solutions $\left(\mathbf{A}-\mathrm{C}_{\mathrm{PEG}}=170 \mathrm{mg} \mathrm{ml}^{-1} ; \mathbf{B}-\mathrm{C}_{\mathrm{PEG}}=240 \mathrm{mg} \mathrm{ml}^{-1}\right)$ at different temperatures.

$1-22{ }^{\circ} \mathrm{C}, 2-80^{\circ} \mathrm{C}, 3-80 \rightarrow 22^{\circ} \mathrm{C} ; \mathrm{C}_{\mathrm{DNA}}=15 \mu \mathrm{g} \mathrm{ml}^{-1} ; 0.3 \mathrm{M} \mathrm{NaCl}+0.002 \mathrm{M} \mathrm{Na}^{+}$-phosphate buffer:

$\Delta \mathrm{A}=\left(\mathrm{A}_{\mathrm{L}}-\mathrm{A}_{\mathrm{R}}\right) \times 10^{-6}$ optical units; $\mathrm{L}=1 \mathrm{~cm}$ 
One can see that at room temperature the dispersions obtained in domain II, where the cholesteric ordering of ds DNA molecules is possible, do not demonstrate an abnormal band in the $\mathrm{CD}$ spectrum (Fig. 2, $A$, curve 1). In addition, the dispersions obtained in domain III, where the hexagonal packing of ds DNA molecules can exist (Fig. 2, B) do not reveal an abnormal band in the CD spectra.

Fig. 2 clearly shows that the formation of dispersions from high molecular mass ds DNA, by itself, is not a sufficient condition for an appearance of abnormal band in the $\mathrm{CD}$ spectrum. Indeed, many aggregated forms of DNA molecules (for instance, the aggregates formed by single-stranded DNA molecules) fail to show the intense band in the CD spectra. Any random packing of nucleic acids is unaccompanied by any change in the amplitude of the $\mathrm{CD}$ band except that produced by changes in secondary structure $[17,24]$.

The heating of both types of dispersions (Fig. 2) does not result in significant optical effect and the small amplitudes of the bands in the CD spectra do not practically change at temperature rise.

Hence, we can assert that the used technology of the phase exclusion (condensation of DNA; see Experimental) in case of high molecular mass ds DNA results only in formation of random aggregates from these molecules.

\subsection{Dispersion particles obtained from linear, rigid and flexible ds DNA molecules in domain II}

Fig. 3, $A$ shows, as an example, the dependence of the abnormal band amplitude in the CD spectrum of the dispersion formed by linear, rigid ds DNA molecules $\left(\mathbf{M}_{3}\right.$, molecular mass is about $\sim 0.3 \times 10^{6} \mathrm{Da}$ ( $\sim 500$ base pairs), $C_{\text {PEG }}=170 \mathrm{mg} \mathrm{ml}^{-1}$; domain II) upon temperature.

The high value of initial negative abnormal band amplitude $\left(\Delta \mathrm{A}_{270}\right)$ at room temperature reflects the long-range spatial twisting (the cholesteric ordering) of ds DNA molecules in the dispersion particles obtained from these molecules.
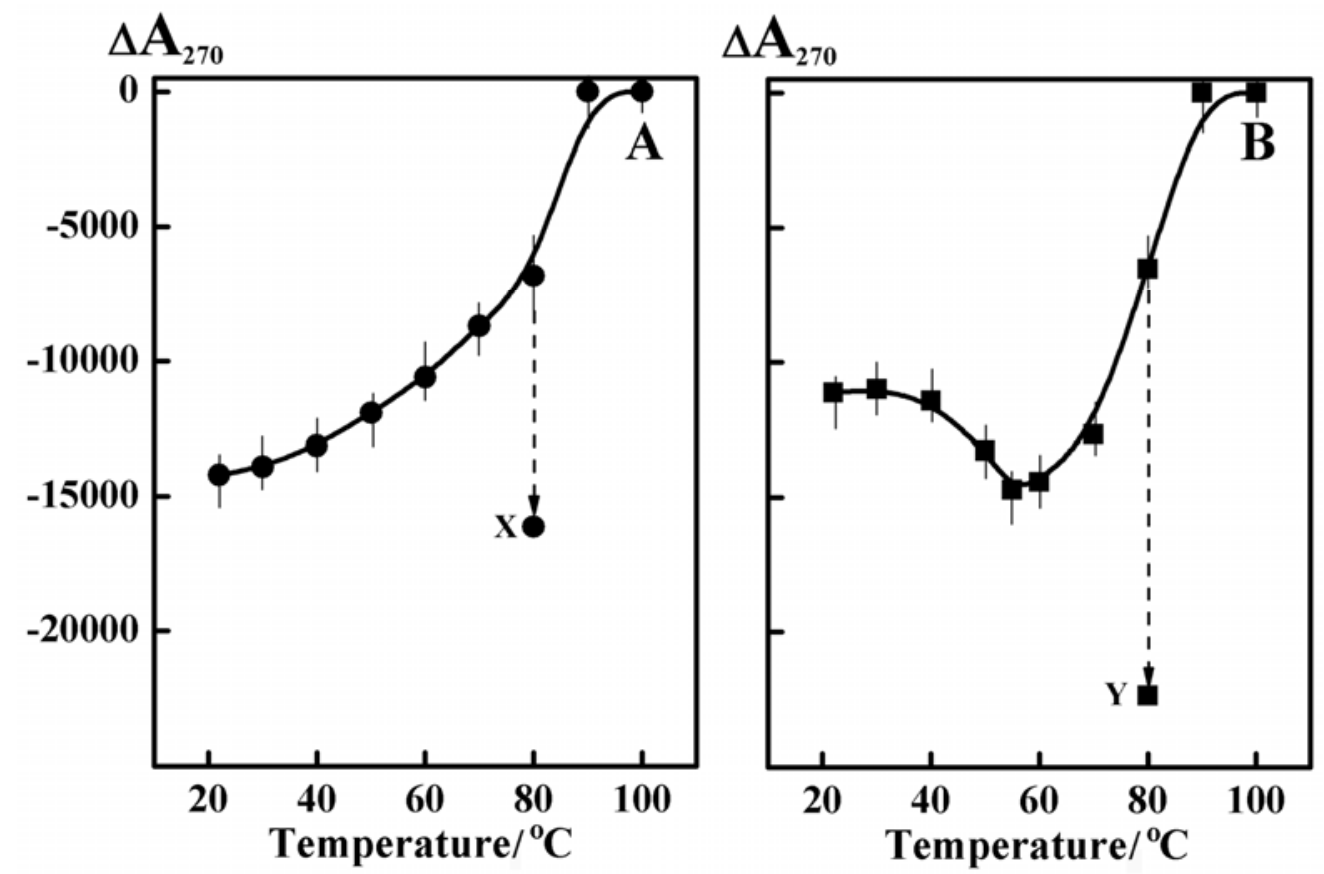

Fig. 3. The dependence of the abnormal band amplitude in the CD spectrum $(\lambda=270 \mathrm{~nm})$ of the the cholesteric LCDs formed by linear, rigid (A) and flexible (B) ds DNA molecules upon temperature.

$\mathbf{X}$ and $\mathbf{Y}$ mean the averaged values of the abnormal band amplitudes for a few LCDs after their thermal training. $\mathrm{C}_{\mathrm{DNA}}=30 \mu \mathrm{g} \mathrm{ml}^{-1}, 0.3 \mathrm{M} \mathrm{NaCl}+0.002 \mathrm{M} \mathrm{Na}^{+}$-phosphate buffer. $\Delta \mathrm{A}_{270} \times 10^{-6}$ optical units, $\mathrm{L}=1 \mathrm{~cm}$ 
Despite the increase in temperature ds DNA molecules cannot "leave" the limited physical volume of dispersion particles, and separation of ds DNA chains in these particles is impossible by steric constrains [36]. (Note that the "melting temperature" $\left(\mathrm{T}_{\mathrm{m}}\right)$ of ds DNA secondary structure (i.e., temperature at which the chains separation of linear ds DNA molecules takes place) in the solutions used in our experiments $\left(0.3 \mathrm{M} \mathrm{NaCl}+0.002 \mathrm{M} \mathrm{Na}^{+}\right.$-phosphate buffer $(\mathrm{pH} \sim 7.0)+\mathrm{PEG})$, is close to $95{ }^{\circ} \mathrm{C}[6]$. The peculiarities of this process have been carefully investigated in a whole series of papers [36-38]).

The thermal decrease of the abnormal band amplitude in the CD spectrum of ds DNA cholesteric liquid-crystalline dispersion (CLCD) particles corresponds to the unwinding of the helical spatial structure of particles formed by DNA molecules, which is known as the "CD melting" [37]. This process depends on the PEG concentration [4] and occurs at a temperature below $\mathrm{T}_{\mathrm{m}}$.

The cooling of the dispersions formed by rigid ds DNA molecules (molecular mass about $0.3 \times 10^{6} \mathrm{Da}$ ) in domain II to room temperature is accompanied usually by the recover of the of abnormal band in the CD spectrum (point $\mathbf{X}$, Fig. 3, A) typical of initial ds DNA CLCD. This optical effect testifies that in dispersion particles formed at phase exclusion of rigid DNA, the high extent of ordering (the "perfect" ordering) of adjacent molecules is reached even at room temperature.

Fig. 3, $B$ demonstrates the dependence of the abnormal band amplitude in the CD spectrum of the CLCD obtained from flexible ds DNA molecules $\left(\mathbf{M}_{2}\right.$, molecular mass is about is about $1.0 \times 10^{6} \mathrm{Da} ; \mathrm{C}_{\mathrm{PEG}}=$ $170 \mathrm{mg} \mathrm{ml}^{-1}$; domain II) upon temperature.

Comparison of Fig. 3, $A$ to Fig. 3, $B$ makes possible a few remarks.

i) The initial value of the abnormal band amplitude $\left(\triangle \mathrm{A}_{270}\right)$ in the $C D$ spectrum of dispersion formed by flexible ds DNA molecules is smaller (Fig. 3, B) than that of in the the CD spectrum of dispersion of rigid ds DNA molecules (Fig. 3, $A$ ). It allows one to suppose that at room temperature these is an "imperfect" long-range ordering of the flexible ds DNA molecules in the CLCD particles.

ii) The prominent growth of the initial abnormal band amplitude in the $\mathrm{CD}$ spectrum precedes the $\mathrm{CD}$ melting (Fig. 3, B). This optical effect was shown at the first time in paper [37]. It confirms mutual alignment (adjustment) of positions of the neighboring flexible ds DNA molecules inside the dispersion particles induced by temperature rise.

iii) The $\mathrm{CD}$ melting takes place at the temperature below $\mathrm{T}_{\mathrm{m}}$.

iv) The cooling of the dispersion particles formed by flexible ds DNA molecules to room temperature, which is accompanied by better ordering of these molecules, results in significant amplification of the abnormal band amplitude in the $\mathrm{CD}$ spectrum (point $\mathbf{Y}$, in Fig. 3, $B$ ).

It may be useful to keep in mind also that the abnormal band $(\triangle \mathrm{A})$ in the $\mathrm{CD}$ spectrum depends upon the spatial parameters of CLCD particles, i.e., their diameter (D) and the cholesteric pitch (P) (see Addendum, Figs. $A-1$ and $A-2$ ). At fixed concentration, the number of dispersion particles in the case of flexible DNA molecules is less that in the case of rigid DNA molecules. However, the higher $\Delta \mathrm{A}$ value (after thermal training) in the case of CLCD particles obtained from flexible ds DNA molecules (Fig. 3, $B$ ) is connected, more probably (highly likely), with the bigger size of these particles after ordering of flexible molecules in comparison to the CLCD particles obtained from rigid ds DNA molecules (Fig. 3, A).

Despite the marked differences, the aforementioned alterations in the $\mathrm{CD}$ spectra upon heating and cooling are typical of the ds DNA LCD with cholesteric-like ordering of molecules (the domain II of PEG osmotic pressure [6]).

\subsection{Dispersion particles obtained from linear, rigid and flexible ds DNA molecules in domain III}

The alignment of the ds DNA molecules in the particles formed in domain III (Fig. 1, $B$; $\mathrm{C}_{\mathrm{PEG}}$ from 220 to $300 \mathrm{mg} \mathrm{ml}^{-1}$ ) was investigated. We assume that the maximal density of ds DNA molecules in the LCD particles can be achieved at their hexagonal packing. In this case we admit the existence of orientationally ordered molecular layers (quasinematic layers) according to the three main directions of the hexagonal structure [32].

The ds DNA molecules are oriented in a plane of these layers with a thickness of the order of the intermolecular spacing.

In Fig. 4 the CD spectra of ds DNA LCD obtained from rigid and flexible ds DNA molecules $\left(\mathrm{C}_{\mathrm{PEG}}=260 \mathrm{mg} \mathrm{ml}^{-1}\right.$; domain III) at their heating and cooling are shown, as an example. This Figure shows that the heating of ds DNA dispersions with the 

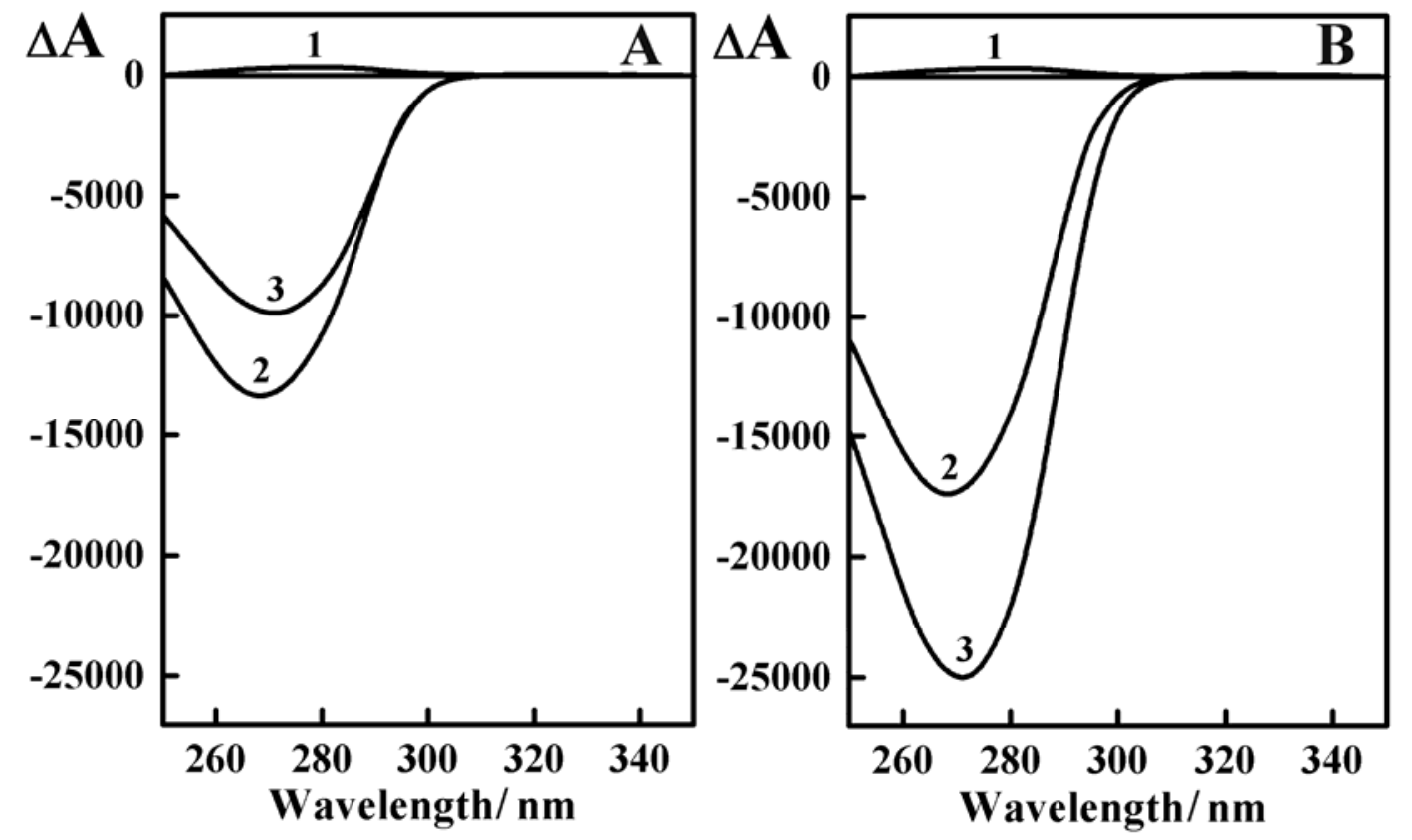

Fig. 4. The CD spectra of the LCDs formed by rigid (A) and flexible (B) ds DNA molecules in PEG-containing aqueous-salt solution $\left(\mathrm{C}_{\mathrm{PEG}}=260 \mathrm{mg} \mathrm{ml}^{-1}\right)$ at different temperatures.

$1-22{ }^{\circ} \mathrm{C}, 2-80^{\circ} \mathrm{C}, 3-80{ }^{\circ} \mathrm{C} \rightarrow 22{ }^{\circ} \mathrm{C} . \mathrm{C}_{\mathrm{DNA}}=30 \mu \mathrm{g} \mathrm{m} l^{-1} ; 0.3 \mathrm{M} \mathrm{NaCl}+0.002 \mathrm{M} \mathrm{Na}^{+}$-phosphate buffer.

$\Delta \mathrm{A}=\left(\mathrm{A}_{\mathrm{L}}-\mathrm{A}_{\mathrm{R}}\right) \times 10^{-6}$ optical units; $\mathrm{L}=1 \mathrm{~cm}$

hexagonal packing of molecules formed in domain III (these particles do not possess an abnormal optical activity at room temperature (curve 1 in Figs. 4, $A$ and $4, B)$ is accompanied by the appearance of a "new abnormal" band in the CD spectra of dispersion particles, i.e., an amplification of band take place.

The extent of amplification of the initial band in the CD spectrum depends on the molecular mass of ds DNA samples. The abnormal band is not typical of hexagonal, but of cholesteric packing of ds DNA molecules (Fig. 1 and Fig. 3); hence, this band reflects the hexagonal $\rightarrow$ cholesteric transition, which is realized inside individual dispersion particles.

The heating of the ds DNA dispersion formed at $\mathrm{C}_{\mathrm{PEG}}=300 \mathrm{mg} \mathrm{ml}^{-1}$ is accompanied again by an appearance of an abnormal band in the CD spectrum (data not shown).

Evidently the packing of the DNA molecules in the dispersion particles depends not only on the energetic but also on the kinetic factors, which is why, e.g., after the "hexagonal $\rightarrow$ cholesteric phase transition", a drop in the temperature of the solution to room temperature will not result in the immediate restoration of the initial hexagonal packing. Such behavior seems to be quite natural for the first-order phase transitions, where metastable structures (and hysteresis phenomena) are possible.

Thus, the heating of the independent LCD particles with the initial cholesteric packing of the ds DNA molecules results in the unwinding of their spatial helical structure. This process is accompanied by the decrease in the optical activity. A drop in the temperature of the solution to room temperature is accompanied by the restoration of the initial cholesteric structure. On the contrary, the heating and cooling of the independent LCD particles with the hexagonal ordering of the neighboring ds DNA molecules results in the appearance of new cholesteric re-entrant phase.

The averaged change of the abnormal optical activity for LCDs obtained from a few samples of rigid and flexible ds DNA molecules at their heating and cooling to room temperature are compared in Fig. 5 (curve 1 and curve 2, respectively). Comparison of the curves obtained for various ds DNA samples indicates that the tendency of ds DNA molecules to form "a new optically active state" upon the temperature rise depends definitely on the molecular mass of the ds DNA molecules. 


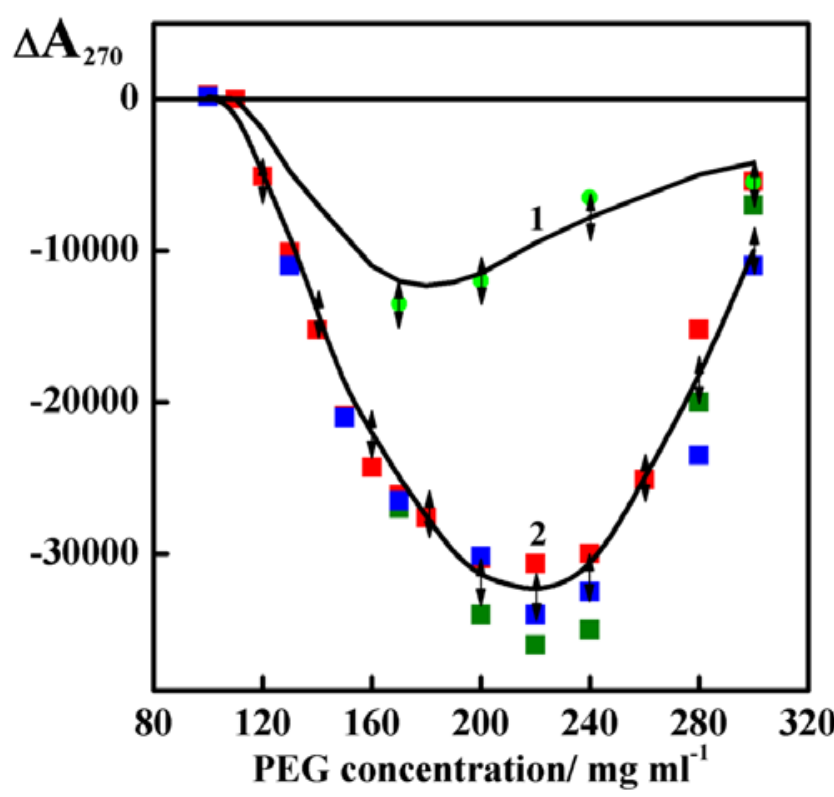

Fig. 5. Dependence of the amplitude of the abnormal band $(\lambda=270 \mathrm{~nm})$ in the CD spectra of various DNA LCDs formed at room temperature, heated to $80{ }^{\circ} \mathrm{C}$ and cooled to room temperature on PEG concentration.

Curve 1 - for ds DNA samples with molecular masses $\mathbf{M}_{3}$. Curve 2 - for ds DNA samples with molecular masses $\mathbf{M}_{2}$. Different symbols correspond to various ds DNA samples. $\mathrm{C}_{\mathrm{DNA}}=30 \mu \mathrm{g} \mathrm{ml}^{-1} ; 0.3 \mathrm{M} \mathrm{NaCl}+0.002 \mathrm{M} \mathrm{Na}^{+}$-phosphate buffer, $\Delta \mathrm{A}_{270} \times 10^{-6}$ optical units; $\mathrm{L}=1 \mathrm{~cm}$

One can note that the results of the theoretical calculations show that the increase in the amplitude of an abnormal negative band in the $C D$ spectrum $\left(\triangle \mathrm{A}_{270}\right.$; Fig. 5, curve 2) of the ds DNA LCDs is related to a decrease in $\mathbf{P}$ value below 2,500 $\mathrm{nm}$ (Addendum, Fig. $A-2)$. It corresponds to the increase in the twist angle between the quasinematic layers existing in the particles of these LCDs. The high values of the amplitude of an abnormal negative band in the CD spectra are existing even for the ds DNA cholesterics with the pitch below $500 \mathrm{~nm}$. But, the measurement of the last value needs the application of special methods.

\subsection{The optical thin layer textures of ds DNA LC phases}

The LC phases (pellets) were obtained as a result of the low-speed sedimentation of the ds DNA dispersion particles formed in PEG-containing solutions.
The ds DNA LC phases have been "compressed" between quartz glasses of thermostated cell and the thin layer optical textures of these phases at various PEG concentrations and temperatures have been compared.

We presented here a number of optical textures we observed in thin layers of the ds DNA LC phases. Taking into account the "compressing" technology of preparation of thin layers of ds DNA phase, the thermal training (i.e. an increase of their temperature to $40-60{ }^{\circ} \mathrm{C}$ ) was used [39-40].

Fig. 6 compares the optical texture of two samples of phases obtained by sedimentation of dispersion particles of ds DNA with high molecular mass $\left(\mathbf{M}_{1} ; \mathrm{C}_{\mathrm{PEG}}=170 \mathrm{mg} \mathrm{m}^{-1}\right.$ (domain II, Fig. 6, A) and $\mathrm{C}_{\mathrm{PEG}}=240 \mathrm{mg} \mathrm{ml}^{-1}$ (domain III, Fig. 6, $B$ ) at various temperatures. These textures, despite different concentrations of PEG used for formation of these phases, contain at room temperature, only the attributes of nonspecific, anisotropic fragments. The increase in temperature to $60{ }^{\circ} \mathrm{C}$ does not accompanied by an essential visual change in shown patterns.

Hence, the textures of the phases obtained from high molecular mass DNA dispersion particles do not allow to determine the presence of specific spatial packing of ds DNA molecules. This result coincides with results, which follow from Fig. 2, about absence of spatial alignment of neighboring high molecular mass ds DNA molecules in aggregates obtained by the used technology of phase exclusion.

Fig. 7, $A$ shows the texture typical of phase obtained at sedimentation of dispersion particles of ds DNA with molecular mass $\mathbf{M}_{3}\left(C_{\mathrm{PEG}}=170 \mathrm{mg} \mathrm{ml}^{-1}\right.$, domain II). The well-known fingerprint texture can be observed both with parallel and crossed polars. This texture is typical of twisted structure (cholesteric) of liquid crystal formed by ds DNA molecules. The cooling of the DNA LC phase from $60{ }^{\circ} \mathrm{C}$ to room temperature does not result in the disappearance of the fingerprint texture.

Several conclusions follow from Fig. 7, A. First, one can see that size of cholesteric domains is much larger in comparison to that of ds DNA dispersion particles $(\sim 500 \mathrm{~nm})$. Secondly, the size of these objects indicates that ds DNA dispersion particles are capable of merging and forming extended cholesteric LC phase. The periodic alteration of light and dark lines in this pattern allows us to estimate the value of the pitch $(\mathbf{P})$ of cholesteric structure formed by the ds DNA molecules. 

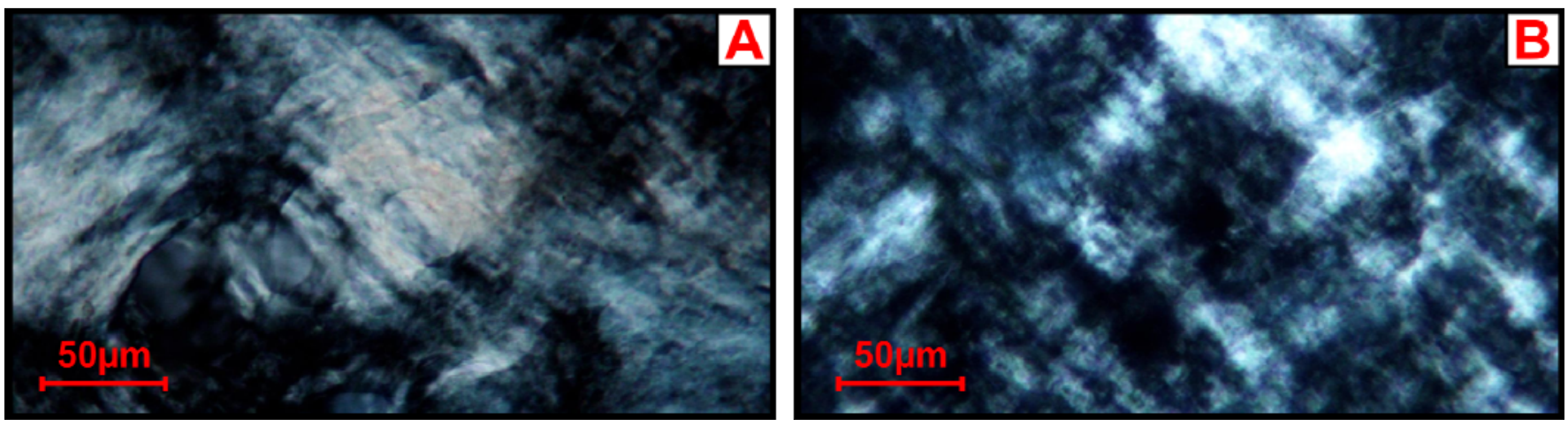

Fig. 6. $\mathbf{A}$ - Thin layer optical texture of the ds DNA phase formed as a result of the low-speed sedimentation of the ds DNA particles formed in PEG-containing solution $\left(\mathrm{C}_{\mathrm{PEG}}=170 \mathrm{mg} \mathrm{ml}^{-1}\right)$. Molecular mass of DNA - M1. Bar $50 \mu \mathrm{m}$

B - Thin layer optical texture of the ds DNA phase formed as a result of the low-speed sedimentation of the ds DNA particles formed in PEG-containing solution $\left(\mathrm{C}_{\mathrm{PEG}}=240 \mathrm{mg} \mathrm{ml}^{-1}\right)$. Molecular mass of DNA - $\mathbf{M}_{\mathbf{1}}$. Bar $50 \mu \mathrm{m}$
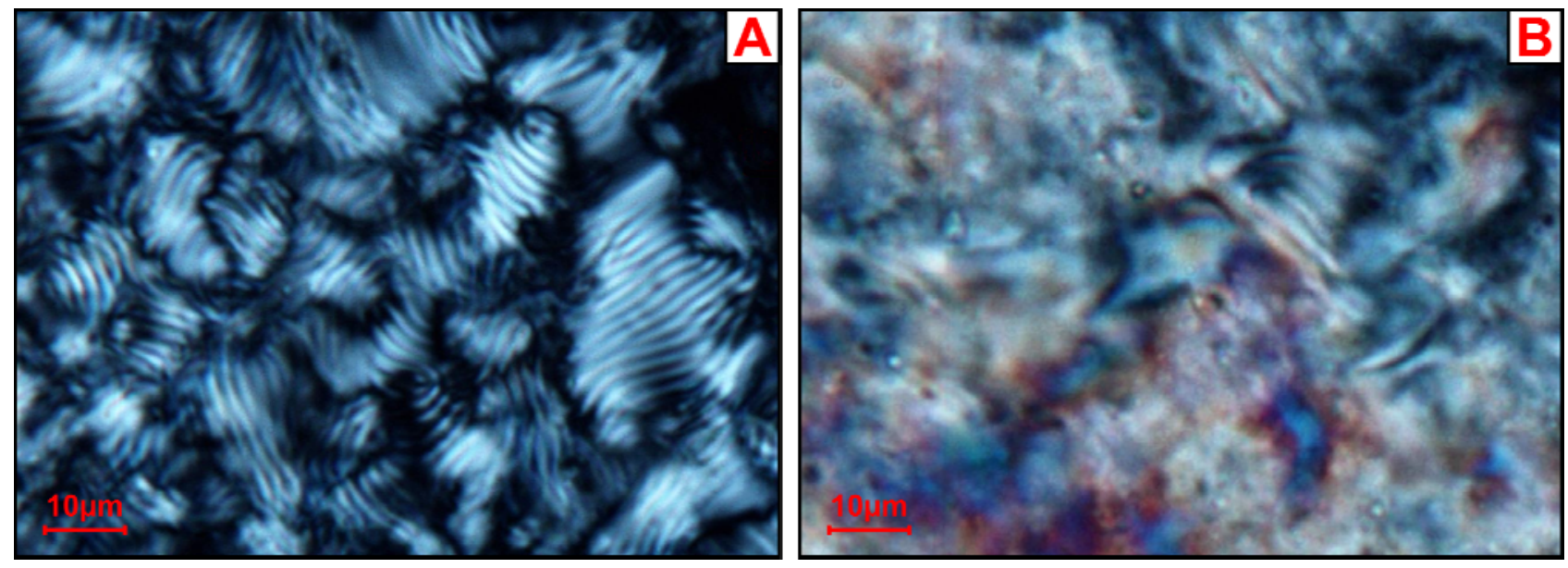

Fig. 7. A - Thin layer fingerprint texture of the bulk LC phase formed as a result of the low-speed sedimentation of the independent ds DNA LCD particles formed in PEG-containing solution $\left(\mathrm{C}_{\mathrm{PEG}}=170 \mathrm{mg} \mathrm{ml}^{-1}\right)$.

Molecular mass of DNA - M3. Bar $10 \mu \mathrm{m}$

B - Thin layer optical texture of the ds DNA LC phase formed as a result of the low-speed sedimentation of the independent ds DNA LCD particles formed in PEG-containing solution $\left(C_{\mathrm{PEG}}=200 \mathrm{mg} \mathrm{ml}^{-1}\right)$.

Molecular mass of DNA - M $\mathbf{M}_{3}$. Bar $10 \mu \mathrm{m}$

One can see small site with fingerprint texture in the right corner of Fig. 7, $B$.

We find that the pitch is on the order $3,000 \mathrm{~nm}$ (within temperature range from $25{ }^{\circ} \mathrm{C}$ to $60{ }^{\circ} \mathrm{C}$ ). Because of inhomogeneous orientation of neighboring cholesteric domains in LC phase it is difficult to measure more accurately the temperature dependence of the pitch value. (According to experimental results [16] the cholesteric pitch value seems to be independent on ds DNA concentration, and its value is not changing with molecular mass of ds DNA molecules. Note that theoretical consideration relates the cholesteric pitch with the length of DNA fragments [41]).

Taking into account that the distance (d) between ds DNA molecules under experimental conditions is close to $3.4 \mathrm{~nm}$, the twist angle $(\varphi)$ between ds DNA molecules in the cholesteric structure corresponds to about $0.4^{\circ}$.

Hence, the thin layer optical textures of the cholesteric LC phase obtained by low speed sedimentation of ds 
DNA dispersion particles in PEG-containing solution demonstrate that the packing of the ds DNA molecules in LC phase does not differ from that of in dispersion particles. The results obtained for cholesteric LC phase and for the ds DNA dispersion particles (Fig. 7, $A$ and Fig. 1) are inherently correlated. It means that both approaches, i.e. the CD spectroscopy and the analysis of textures, permit to detect the cholesteric mode of ds DNA molecules packing.

Thus, under $170 \mathrm{mg} \mathrm{ml}^{-1}$ of PEG in solution there is no difference in the mode of the ds DNA molecules packing in the independent dispersion particles and in the bulk LC phase.

We have investigated also the thin layer optical textures of LC phases obtained from the ds DNA dispersion particles with hexagonal packing of these molecules (PEG concentration is $200-300 \mathrm{mg} \mathrm{ml}^{-1}$ ). (It was shown above (Fig. 5) that these ds DNA dispersion particles form the "re-entrant cholesteric phase" at temperature rise).

The thin layer optical texture of LC phase formed at PEG concentration $200 \mathrm{mg} \mathrm{ml}^{-1}$ (conditions, which correspond the intermediate concentration of
PEG, Fig. 1), is dramatically different from the previous case (Fig. 7, $A$ ). Fig. 7, $B$ shows the optical texture taken with crossed polars. In contrast to the previous case, this pattern contains only minor fragments with fingerprint texture. Main part of this texture has the attributes of anisotropic object, where deep red and blue colors are present.

Similar development of colors takes place in the case of LC phase formed at PEG concentration $240 \mathrm{mg} \mathrm{ml}^{-1}$, i.e., under conditions, which correspond to the hexagonal packing of ds DNA molecules (molecular mass $\mathbf{M}_{3}$, Fig. 8, $A$ ). At room temperature pattern contain only nonspecific anisotropic domains. The increase in temperature of the thin layer is accompanied by development of colored sites.

We observe analogous pattern for case of LC phase formed at PEG concentration $260 \mathrm{mg} \mathrm{ml}^{-1}$, i.e., under conditions, which correspond again to the hexagonal packing of ds DNA molecules. At room temperature pattern contain only nonspecific anisotropic domains. The increase in temperature of the thin layer is accompanied by development of colored sites.
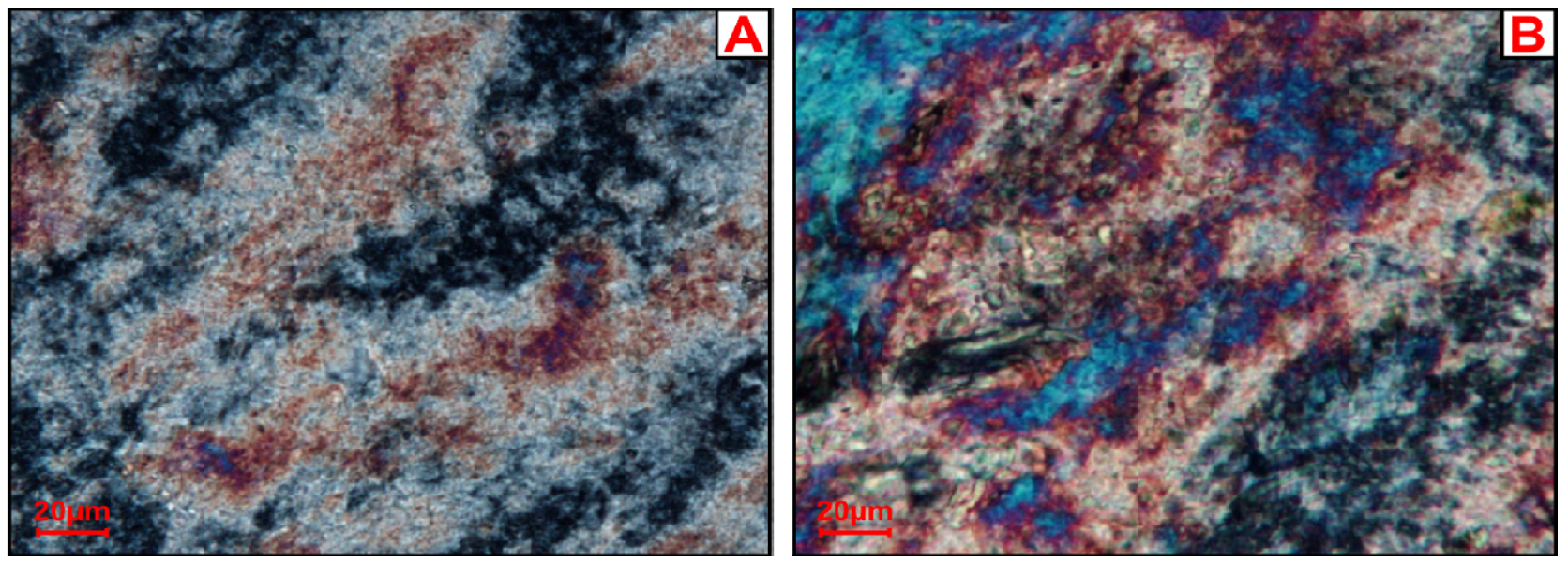

Fig. 8. A - Thin layer optical texture of the bulk LC phase formed as a result of the low-speed sedimentation of the ds DNA LCD particles formed in PEG-containing solution $\left(\mathrm{C}_{\mathrm{PEG}}=240 \mathrm{mg} \mathrm{ml}^{-1}\right)$. Molecular mass of DNA $-\mathbf{M}_{3}$. Bar $20 \mu \mathrm{m}$

B - Thin layer optical texture of the bulk LC phase formed as a result of the low-speed sedimentation of the ds DNA LCD particles formed in PEG-containing solution $\left(\mathrm{C}_{\mathrm{PEG}}=300 \mathrm{mg} \mathrm{m}^{-1}\right)$. Molecular mass of DNA $-\mathbf{M}_{3}$. Bar $20 \mu \mathrm{m}$

At the further increase of PEG concentration to $300 \mathrm{mg} \mathrm{m}^{-1}$ (molecular mass $\mathbf{M}_{3}$; Fig. 8, B) the alterations in the thin layer texture of ds DNA phase are continued. Again, at room temperature the optical texture typical of any known LC system is absent. The texture taken with crossed polars demonstrates the presence only a small amount of anisotropic sites. The increase of temperature results in an increase of the number of these anisotropic sites. At high temperature the sites with blue or deep red color are appeared. In this case the color tends to return back to that of initial thin layer texture. 
Hence, the textures of phases formed from independent dispersion particles with the hexagonal packing of ds DNA molecules (domain III) do not demonstrate even at increase of temperature the attributes of the re-entrant cholesteric phase.

\section{Discussion \\ 4.1. The CD spectra of ds DNA LCD particles}

First of all, we remind the properties of ds DNA dispersions formed in PEG-containing solutions as a result of phase exclusion of DNA molecules. It is necessary specially to mark that in this case the ds DNA dispersion particles exist as independent objects. For these objects are important the following peculiarities.

1. Above some "critical" osmotic pressure of the solution, that is necessary for ds DNA condensation, the condensing agent (PEG) is completely excluded from the DNA-rich phase, i.e. from ds DNA LCD particles [42-47].

2. The size (diameter) of the ds DNA LCD particle is determined by a fine balance between the free energy of these particles and their surface free energy [16, 21, 46-48]. The bulk free energy of an LCD particle tends to increase the particle size. The surface free energy (which depends on the surface tension of the condensed phase) tends to decrease the interface separating the DNA-rich phase and the isotropic solution. This competition suggests the existence of a certain critical size of the LCD particles below which they are unstable or do not form at all. The average distance between the ds DNA molecules is determined by a balance between repulsive intermolecular forces and the compressing osmotic pressure of the PEG solution.

The size of dispersion particles depends on osmotic pressure of PEG, i.e., the higher osmotic pressure, the smaller the size of dispersion particles $[6,16]$.

Hence, the size of ds DNA dispersion particles formed in domain III is smaller than that of in domain II.

3. The ordering of ds DNA molecules in dispersion particles depends, in turn, on molecular mass of ds DNA, which determines the flexibility of molecules [49-52].

4. The minimization of the excluded volume of the neighboring linear, rigid (and event flexible) ds DNA molecules is realized for the parallel (nematiclike) alignment of ds DNA molecules (or their segments) forming the quasinematic layers. The chiral and anisotropic properties of ds DNA molecules favor the helical twist of these molecules and, therefore, the quasinematic layers. Hence, unidirectional alignment of the ds DNA molecules competes with their tendency to twist (to form twisted (cholesteric-like) structure of the LCD particles).

For the rigid ds DNA molecules containing chromophores (nitrogen bases), one can expect the appearance of an abnormal band in the CD spectrum (Fig. 1). Comparison of our experimental measurements and results of calculations univocally testifies to the macroscopic (cholesteric) twist of neighboring nitrogen bases in the content of the LCD particles. In the case of the ds DNA B-form, nitrogen bases are rigidly fixed at $90^{\circ}$ with respect to the long axis of the ds DNA molecule. Hence, the twisted structure of DNA nitrogen bases leads to the twisted location of neighboring, linear, rigid ds DNA molecules. Measuring of the CD spectra allows one to determine different structural state of ds DNA molecules.

In the case of the ds DNA LCD particles (at room temperature) the following phase transitions: "isotropic (I) $\rightarrow$ cholesteric (II) $\rightarrow$ hexagonal state (III)" is easy realized; it is governed by an increase of the PEG concentration in a solution [6]. These structural states differ by the shape of CD spectra. Fig. 1 shows that in domain II the cholesteric structures (with abnormal band in the CD spectra) are characteristic of the ds DNA LCD particles. The ds DNA dispersions particles formed in the domain III $\left(\mathrm{C}_{\mathrm{PEG}}\right.$ from 220 to $300 \mathrm{mg} \mathrm{ml}^{-1}$, Fig. 1) are the hexagonal structures of ds DNA LCD particles, which do not possess abnormal bands in the CD spectra. The local structure in this case consists of straight ds DNA chains with parallel nematic alignment minimizing the bending energy [53].

5. Due to the osmotic pressure (determined by PEG concentration), the spatial structure of the DNA LCD particles in a PEG-containing solution is sterically confined ("frozen"). Nevertheless, the DNA molecules retain some diffusion degrees of freedom, which lead to their "liquid-like" packing in the dispersions.

6. The increase in the temperature is accompanied by a decrease of the PEG-containing solution viscosity and as a result it reduces the effective osmotic pressure $[54,55]$. Under these conditions, the thermal motions of the neighboring ds DNA molecules in LCD particles increase. As a result, depending on density of ds molecules packing different thermal transitions can take place, like the melting of spatial structure of dispersion particles or formation of a new spatial structure of dispersion particles. 
Bearing said above in mind, let discuss result the peculiarities of the CD spectra of dispersion particles obtained by the technology described in Experimental.

Fig. 2 shows that the phase exclusion (condensation) of a very high molecular mass ds DNA molecules (molecular mass $\sim 10 \times 10^{6} \mathrm{Da}$ ) at conditions of domain II (Fig. 2, $A$ ) and domain III (Fig. 2, $B$ ), does not accompanied an appearance an abnormal band in the $\mathrm{CD}$ spectra. The shapes of the CD spectra are typical of random aggregates. It is not excluded that in these aggregates ds DNA molecules or their segments can rotate independently around their long axes and their chiral interactions can be averaged out. An absence of "rotational correlations" between molecules means absence of chiral interactions [56,57]. This, in turn, yields to the absence of abnormal optical activity for such ds DNA aggregates $[35,58]$.

Hence, the specific spatial alignment of very flexible ds DNA molecules is absent in the dispersion particles of a very high molecular mass ds DNA molecules at room (and higher) temperatures.

Fig. 3, $A$ reveals that the "short", rigid, ds DNA molecules (molecular mass $(0.2-0.3) \times 10^{6} \mathrm{Da}$ ) form at phase exclusion in domain II at room temperature the dispersion particles with almost "perfect" cholesteric packing of ds DNA molecules. Comparing Fig. 3 to Fig. 2 demonstrates that the cholesteric packing of ds DNA molecules, in contract to disordered or random aggregation of ds DNA molecules, is accompanied by an appearance of the abnormal band in the CD spectrum. Hence, in the case of rigid ds DNA molecules the cholesteric mode of packing is easily realized, because in such a case there are almost no any physical restrictions even at room temperatures. The thermal training of dispersion particles obtained from rigid ds DNA molecules almost does not affect their initial ordering.

Upon decreasing the ds DNA molecular mass, for instance, from $10 \times 10^{6} \mathrm{Da}$ to $1 \times 10^{6} \mathrm{Da}$, the molecular flexibility is also decreased. The flexible ds DNA molecules (molecular mass $\left(\mathbf{M}_{2}\right)$ is equal to $\left.(0.5-1.0) \times 10^{6} \mathrm{Da}\right)$ are spontaneously assembled during phase exclusion (in domain II) at room temperature. However, Fig. 3, $B$ shows that due to virtue of kinetic and steric restrictions, flexible molecules can not be packed "ideally" in the cholesteric dispersion particles (sliding or rolling of neighboring DNA segments can induce their irregular ordering). The theoretical calculations presented in Fig. A-3 (Addendum), show that appearance of a finite angle between linear neighboring ds DNA segments (which was used as an indication of higher flexibility of DNA molecules) is indeed accompanied by the decrease in abnormal band amplitude the $\mathrm{CD}$ spectrum of dispersion particles. Embodying "ideal" cholesteric packing of flexible ds DNA molecules needs in this case the additional energy to change their spatial locations to that corresponding to their spatial twist. Some sort of annealing process is necessary for creation of the "ideal" packing of the flexible ds DNA molecules. Comparison of Fig. 3, $B$ to Fig. A-1 (Addendum) definitely shows that the thermal training of dispersion particles obtained from flexible ds DNA molecules results in their "linearization" in quasinematic layers and the increase of the size of such particles with subsequent increase in abnormal band amplitude the CD spectrum.

Hence, the flexibility of independent ds DNA molecule plays a significant role in their LC assembly, which takes place in domain II and accompanied by formation of dispersion particles with cholesteric packing of molecules. It is an important factor, which can be used to fine tune the parameters of the cholesteric structure of ds DNA dispersion particles and their abnormal band in the CD spectrum.

Fig. 4, $A$ and Fig. 4, $B$ show as, an example, the results of the thermal training of the independent particles with the hexagonal ds DNA molecules packing in domain III (molecular masses $\mathbf{M}_{\mathbf{2}}$ and $\mathbf{M}_{\mathbf{3}}$ ). The heating of independent ds DNA dispersions with the hexagonal packing of DNA molecules, is accompanied by an unusual optical effect: at temperature increase an intense band arises in the CD spectrum of the ds DNA dispersions that do not exhibit an abnormal band at room temperature. The sharp increase in the optical activity of the ds DNA dispersion particles looks like a phase transition and represents by itself univocal evidence of a change in the spatial orientation of the ds DNA quasinematic layers in the structure of the hexagonal dispersion particles. It suggests that the cholesteric-like packing reappears upon the heating of dispersions with hexagonal ordering of the ds DNA molecules (hence, term "cholesteric re-entrant"). This new, negative abnormal band (usually) does not recover its initial value upon the cooling the dispersion from $80{ }^{\circ} \mathrm{C}$ to the room temperature.

The control experiments by the "external chromophores" method [19,32] (compounds 
intercalating only between nitrogen base pairs of B-form of ds DNA molecules) have shown that the processing dispersions obtained in domain III after the temperature increase (with abnormal band in the CD spectra) by these compounds results in the appearance of an additional abnormal band in the CD spectrum in the visible region. This effect confirms that the parameters of the DNA secondary structure do not change at temperature increase [32].

Fig. 5 summarizes the results obtained for a few ds DNA samples. Indeed, at certain temperature the hexagonal packing (domain III) of the ds DNA quasinematic layers in independent dispersion particles becomes labile and in the absence of other external influences, we can expect that instead of the "melting" of the hexagonal structure, the stable (or metastable) spatial, helically twisted (a new cholesteric re-entrant) structure (with the abnormal band in the CD spectrum) can be formed even at a relatively high PEG osmotic pressure. Spatial twist of the rigid ds DNA molecules is easily realized, because of the absence of kinetic restrictions. Formation of a new cholesteric re-entrant state depends upon PEG concentration (the higher PEG, the higher temperature of re-entrant state appearance).

Fig. 5 shows as well that the sharp increase in the optical activity of the ds DNA dispersion particles depends on molecular masses of the DNA samples.

Taking into account results obtained for ds DNA with very high molecular mass (Fig. 2), the difference between curves 1 and 2 in Fig. 5 clearly shows that for formation of cholesteric re-entrant state the"optimal" molecular mass $\left(\mathrm{M}_{\text {opt. }}\right)$ of ds DNA molecules can be fixed within range $0.3 \times 10^{6} \mathrm{Da}<$ $\mathbf{M}_{\text {opt. }}<1.0 \times 10^{6} \mathrm{Da}$.

It is not excluded that in our experimental conditions (PEG molecular mass, ionic content, etc.) this optimal molecular mass is related to the formation of the independent LC particles with the relatively narrow size distribution [20].

These conditions in combination with the room temperature or additional thermal training of rigid of flexible DNA molecules provide the packing of DNA molecules into the particles of such size, which responsible for their abnormal optical activity. Indeed, the results of the theoretical calculations presented in Addendum support our suggestion. They show (Addendum, Fig. A-1) that the bigger is the size of dispersion particles, the higher is the abnormal band amplitude in the $\mathrm{CD}$ spectrum ( $\triangle \mathrm{A}$ value). If neigh- boring flexible ds DNA molecules can be ordered (as a result of the thermal training) into dispersion particles of bigger size, then they have got a higher abnormal band in the CD spectra. It means that the flexibility of the independent ds DNA molecules play a significant role in their LC assembly. Indeed, the results of theoretical calculations (see Addendum, Fig. A-3) show that abnormal band amplitude in the CD spectrum depends on flexibility of DNA molecules (expressed, for simplicity, as an inclination angle between two neighboring DNA segments. An angle equals to $180^{\circ}$ means that the structure of ds DNA molecule is rigid, because an angle between two neighboring segments is absent).

Therefore, the physicochemical parameters of independent ds DNA molecules, in particular, their molecular mass and flexibility, can influence the ability of these molecules to form the LC particles in domain II and in domain III. These parameters can be used to adjust an abnormal optical activity of the independent ds DNA particles, which are formed in aqueous-salt-PEG containing solutions. It worth to noting that the CD spectra of ds DNA dispersion particles allow one to discriminate the DNA molecules according to their molecular masses. The thermal training of these dispersion particles can improve the "quality" of their packing in dispersion particles or even an appearance of the cholesteric re-entrant packing (stable or metastable) in a certain temperature range.

\subsection{The thin-layer textures of ds DNA LC phases}

The situation is strongly changed in the case of bulk LC phases, obtained from ds DNA dispersion particles.

i). The formation of ds DNA LC phase (pellet) includes the sedimentation of ds DNA dispersion particles, the concentrating of dispersion particles and the merging both the particles and the ds DNA molecules. Hence, local concentration of ds DNA molecules in LC phase may be higher in comparison to the concentration of independent particles, which have been existed in solution.

(It is not excluded, that the morphology of ds DNA LC phase can vary depending on the method of their preparation [59] as well as on the dynamics of the particles coalescence [60]).

ii). The density of neighboring ds DNA molecules packing in dispersion particles, they diffusion mobility and their diffusion mobility (so-to- 
spear "thermal fluidity") can lead to possibility of spatial coalescence of neighboring particles and formation of bulk LC phase. Own (inherent) anisotropic properties of ds DNA molecules determine the optical properties of bulk LC phase and even disordered (random packed) aggregates of DNA molecules.

iii). The interaction between neighboring ds DNA dispersion particles (molecules) can trigger formation of extended LC phase, whereas the anisotropic properties typical of individual ds DNA particles will result in formation of anisotropic domains of different size in LC phase, their spatial position and packing defects within LC phase.

Besides, there are additional interactions between neighboring ds DNA molecules in the bulk LCD phase and cover slip.

iv). In bulk LC phase with hexagonal packing of molecules, thermal rotation of ds DNA molecules around their long axis is suppressed and therefore the strength of chiral interaction between nearest neighbors is diminished [41]. A loss of "biaxial correlations" between ds DNA molecules at the high ds DNA concentration in the LC phase will accompanied by the increase of the probability of cholesteric unwinding at the cholesteric to hexagonal transitions [21-61].

Hence, in contrast to independent ds DNA dispersion particles, which properties are easily adjusted by many factors, the properties of bulk $L C$ phase depends mainly on the mode of interaction between neighboring ds DNA molecules inside dispersion particles and between densely packed ds DNA dispersion particles.

The set of thin layer textures presented in Fig. 7, $A$, Fig. 8, $A$ and Fig. $8, B$ needs several comments.

First of all, the fingerprint textures of the bulk LC phase obtained by low speed sedimentation of independent dispersion particles of ds DNA molecules, which possess abnormal bands in the CD spectra (domain II), univocally confirm the cholesteric mode of packing of these molecules at room and elevated temperature in PEG-containing solutions.

To explain the obtained results it is necessary to keep in mind that ds DNA dispersion particles in domain II have dimension about $500 \mathrm{~nm}$. At the distance between the ds DNA molecules about $3.5 \mathrm{~nm}$ the molecules in the dispersion particles can move with a relatively high mobility. We suppose that under these conditions the anisotropy of the neighboring
DNA molecules and their interactions determine their tendency to twist (i.e., cholesteric twist is predetermined). However, the "liquid-like" behavior of neighboring ds DNA molecules allows the adjacent DNA particles to stick together (to "coalescence") at concentration increase. According to obtained results, the low-speed sedimentation of dispersion particles with initial cholesteric packing of ds DNA molecules does not influence this mode of molecules packing. It results only in formation of local cholesteric domains and in formation of the extended cholesteric LC phase and the cholesteric packing of the ds DNA molecules in LC phase is proven by the fingerprint textures.

Secondly, at room temperature the optical textures of the bulk LC phases presented in Figs. 8, $A$ and $8, B$ do not correspond to the textures of any known ds DNA LC systems [8,39]. In contrast to the texture shown in Fig. 7, $A$ these textures do not contain any attributes of the cholesteric structure (in particular, we do not see the fingerprint texture typical of cholesterics).

The textures (Fig. 7, B, Figs. 8, $A$ and 8, B) demonstrate the presence of relatively extended anisotropic areas visible at crossed polars (but invisible without them). At room temperature a number of such spots is small enough, but the increase in temperature leads to the growth of size of anisotropic areas, and we observed the appearance of the many areas with different colors.

Hence, the textures of phases formed from independent dispersion particles with the hexagonal packing of ds DNA molecules (domain III) do not demonstrate even upon heating and thermal training the attributes of the re-entrant cholesteric phase.

We see plausible effects leading to such behavior.

1. The presence and development of anisotropic areas in the textures of these LC phases (Figs. 8, $A$ and $8, B$ ) in the combination with the absence of the fingerprint texture suggests that the helical pitch of the re-entrant cholesteric phases typical of ds DNA dispersions at high PEG concentrations is much smaller than that of classical cholesterics.

Our theoretical calculations support this suggestion (Addendum, Fig. A-2). They show that for achievement of high value of amplitude of an abnormal band in the CD spectrum (Fig. 5), the pitch "re-entrant cholesteric phase" formed by ds DNA molecules should be lower than $500 \mathrm{~nm}$. However, such pitch can not be measured by means of the polarization microscope. 
2. There is also another reason for observation of specific textures of bulk LC phases obtained from the particles of domain III.

The matter is that initial ds DNA dispersion particles formed in domain III have hexagonal packing at room temperature. Dense packing of ds DNA molecules in these particles influence mutual diffusion of neighboring DNA molecules on the one hand; on the other hand, high concentration of these particles in LC pellet (phase), limits ordered coalescence of neighboring particles. This means that initial hexagonal packing is conserved in the formed bulk LC phase. Investigation of the texture of such phase yet is not described and is not explored.

Hence, we conclude that the mode of ordering of ds DNA molecules within the bulk LC phase can differ from that of in independent particles.

Our observations presented above suggest the reason for the absence in LC phases the packing modes characteristic of dispersions particles. In these phases spatial orientation of neighboring dispersion ds DNA particles can be more or less random. Therefore, the direct correlation between the optical texture of bulk LC phase of ds DNA molecules and concrete mode of molecules packing in independent dispersion particles not always exists.

It is worth to noting also the following biological aspect of our results. It is well-known that for realization of the biological activity of primitive biological organisms, their ds DNA molecules must possess the structure similar to that of the cholesteric structure [5, 8, 62-65].

Our results demonstrate that there is the "hexagonal $\rightarrow$ re-entrant cholesteric" phase transition which is realized at elevated temperatures depending on the peculiarities of ds DNA molecules (their molecular mass, etc). We can speculate that this transition is necessary in the case for thermotropic organisms to realize their biological activity at elevated temperatures [66].

\section{Conclusion}

It is shown that the thermotropic "hexagonal $\rightarrow$ re-entrant cholesteric" phase transition is typical of the hexagonal particles formed by the rigid and flexible ds DNA molecules in water-salt solutions with high PEG concentrations. This transition is accompanied by the appearance of the abnormal band in the CD spectra of the dispersion particles. The system cooperativity at this transition depends on molecular mass of the DNA molecules (provided all other experimental conditions and external parameters are the same). The amplitude of an abnormal band in CD spectrum of re-entrant cholesteric phase can differ from that of "classical" ds DNA cholesterics. Based on our findings we do believe that the existence of re-entrant cholesteric phase with the maximal abnormal band in the CD spectrum is defined by the combination of the optimal conditions (molecular mass of DNA, osmotic pressure and temperature of solution). Our results clearly manifest deceptively simple (but often overlooked) observation that there are multiple local minima (metastable states) for a cholesteric-like structure under competing actions of thermal fluctuation (temperature), osmotic pressure and boundary conditions (anchoring).

The optical textures of the LC phases obtained from dispersion with hexagonal packing of the ds DNA molecules do not correspond to the textures of any known ds DNA LC systems. At temperature increase these textures do not show any specific attributes of the cholesteric structure. This fact might at first sight seem surprising. It manifests that upon sedimentation of the high osmotic pressure dispersion particles (presumably with the hexagonal initial packing of the ds-DNA molecules) produces some irreversible modification of the formed macroscopic phase (texture). At high enough resolution we see also that these textures contain extended anisotropic domains of different size, which are demonstrated by the "play of colors" detectable by the polarization microscope. However we do not see a fingerprint cholesteric texture, because the pitch calculated from the measured value of the abnormal CD is smaller than optical resolution. At high enough resolution we see also that these textures contain extended anisotropic domains of different size, which are demonstrated by the "play of colors" detectable by the polarization microscope.

There is significant difference between the thermal behavior of the independent microscopic size ds DNA dispersions and the macroscopic size LC phases formed from these dispersions at high PEG concentration, though both objects have initially the hexagonal mode of ds DNA molecules packing. The abundance of the observed textures is one more illustration that the cholesterics display a high number of metastable configurations in confined geometry, due the interplay between chirality, elasticity, and surface interactions. The results and observations of our work can be used as a reference for future theore- 
tical, numeric, and experimental studies of ds-DNA dispersion particles and phases. It is worth to noting also a possibility to design new ds DNA LC materials with unusual optical properties.

\section{Acknowledgments}

Yevdokimov Yu.M., Skuridin S.G. and Salyanov V.I. acknowledge the support of the Russian Science Foundation, project № 16-15-00041.

The authors are sincerely grateful to Prof. A.V. Belyavskii (Engelhardt Institute of Molecular Biology of the Russian Academy of Sciences) and Dr. M.A. Eldarov (Bioengineering Center of the Russian Academy of Sciences) for fruitful discussion of the results obtained in this paper.

\section{Addendum}

To calculate the CD spectra of the ds DNA dispersions, a phenomenological model based on the theory of optical properties of nonperfect absorbing cholesteric liquid crystals [67-68] was employed previously [30].

Recently this approach was exploited to further develop a theoretical examination of the abnormal optical properties of ds DNA LCD dispersion particles in various conditions.

Double-stranded DNA dispersions were considered as multicrystalline entities with an arbitrary spatial orientation of independent (individual) particles. It was assumed that single dispersion particles have a LC order with a certain pitch of the helical spatial structure. The ds DNA cholesteric LCD dispersion particle is considered as an ensemble of quasinematic layers containing absorbing dipoles. The distance between neighboring effective layers is $\mathbf{d}$ and the rotation angle between neighboring layers is $\Delta \varphi$.

Our approach is based directly on solving Maxwell's equations; it does not impose principal limitations on the size of dispersion particles, and does not require perfect cholesteric packing in dispersion particles. Owing to these features, the approach can be used to address a broad range of problems in studying the optical activities of ds DNA dispersion particles.
The used model makes it possible to study the effects of various factors on the CD spectra of ds DNA LCDs and estimate the dependences of amplitude of abnormal band in the $\mathrm{CD}$ spectra $(\triangle \mathrm{A})$ upon the physical parameters of dispersion particles, and their concentration.

In Addendum we presented several results of the advanced theoretical calculations, which are interesting in the framework of current paper, i.e., the theoretical dependence of the amplitude of the abnormal band in the $\mathrm{CD}$ spectra $(\triangle \mathrm{A})$ upon the size of the particles of the ds DNA cholesteric LCDs (Fig. $A-1$ ); the theoretical dependence of $\Delta \mathrm{A}$ value upon cholesteric pitch (Fig. $A-2$ ); and the theoretical dependence of $\Delta \mathrm{A}$ value upon the inclination angle between neighboring segments of ds DNA molecules ordered in quasinematic layers (Fig. $A-3$ ).

The theoretical background of our approach is described in [23].

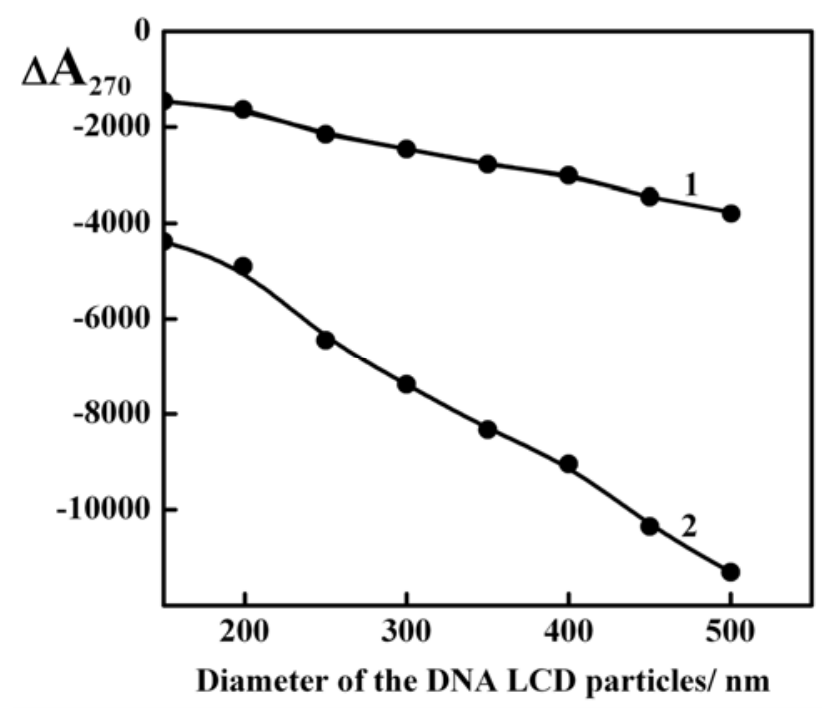

Fig. A-1. Theoretically calculated dependence of the abnormal negative band amplitude $\left(\Delta \mathrm{A}_{270}\right)$ in the $C D$ spectra of the cholesteric ds DNA LCDs upon the size (diameter) of dispersion particles.

$1-\mathrm{C}_{\mathrm{DNA}}=10 \mu \mathrm{g} \mathrm{ml}^{-1}, 2-\mathrm{C}_{\mathrm{DNA}}=30 \mu \mathrm{g} \mathrm{ml}^{-1}$.

$\mathrm{P}=2,500 \mathrm{~nm} ; \Delta \mathrm{A}_{270} \times 10^{-6}$ optical units; $\mathrm{L}=1 \mathrm{~cm}$ 


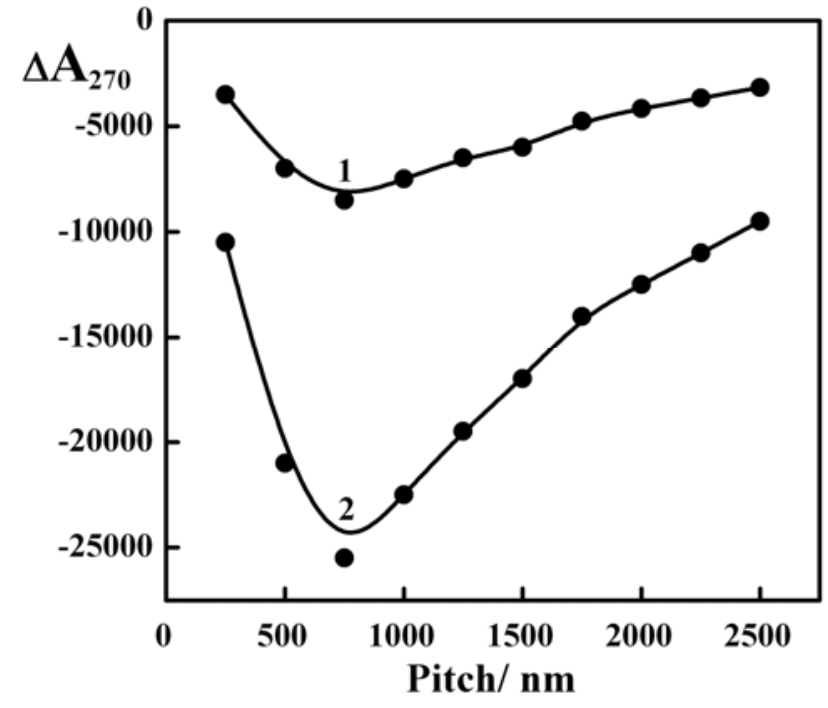

Fig. A-2. Theoretically calculated dependence of the abnormal negative band amplitude $\left(\Delta \mathrm{A}_{270}\right)$ in the $C D$ spectra of ds DNA LCDs upon the cholesteric pitch. $1-\mathrm{C}_{\mathrm{DNA}}=10 \mu \mathrm{g} \mathrm{ml}^{-1}, 2-\mathrm{C}_{\mathrm{DNA}}=30 \mu \mathrm{g} \mathrm{ml}^{-1} . \mathrm{D}=500 \mathrm{~nm}$; $\Delta \mathrm{A}_{270} \times 10^{-6}$ optical units; $\mathrm{L}=1 \mathrm{~cm}$

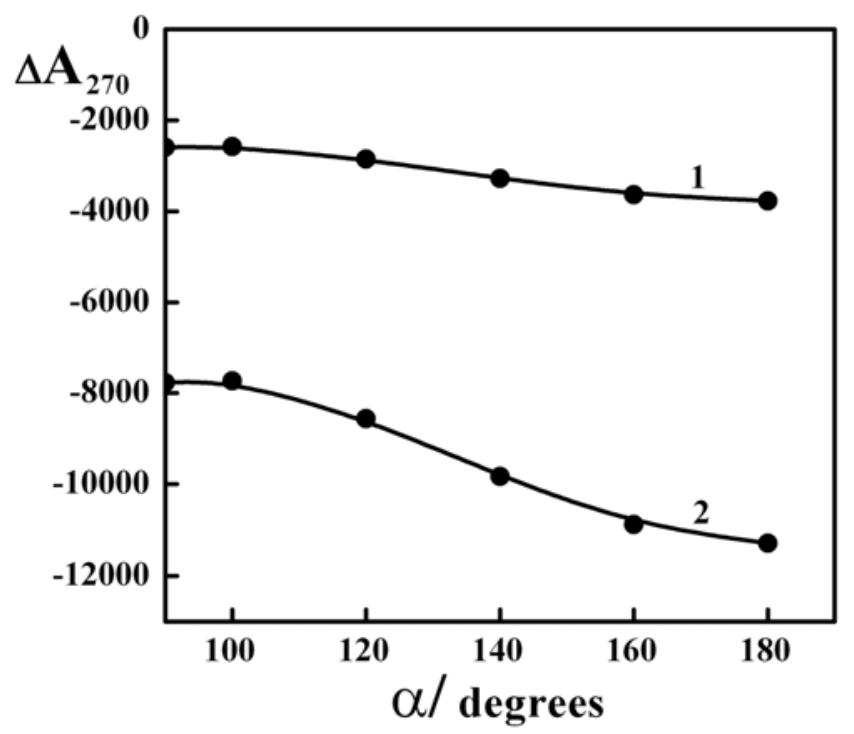

Fig. A-3. Theoretically calculated dependence of the abnormal negative band amplitude $\left(\Delta \mathrm{A}_{270}\right)$ in the $C D$ spectra of the cholesteric ds DNA LCDs upon the inclination angle between two neighboring segments in the content of ds DNA molecules, forming quasinematic layer. $1-\mathrm{C}_{\mathrm{DNA}}=10 \mu \mathrm{g} \mathrm{ml}^{-1}, 2-\mathrm{C}_{\mathrm{DNA}}=30 \mu \mathrm{g} \mathrm{ml}^{-1} . \mathrm{D}=500 \mathrm{~nm}$; $\mathrm{P}=2,500 \mathrm{~nm} ; \Delta \mathrm{A}_{270} \times 10^{-6}$ optical units; $\mathrm{L}=1 \mathrm{~cm}$

\section{References}

1. Robinson C. Liquid crystalline structures in polypeptides solutions. Tetrahedron, 1961, 13 (1-3), 219-234. DOI: 10.1016/S0040-4020(01)92215-X.

2. Bouligand Y. Liquid Crystals and their analogs in biological systems. Solid State Phys., Suppl. 14. / Ed. by L. Liébert. New York : Academic Press, 1978, 259-294.

3. Rill R. Liquid crystalline phases in concentrated aqueous solutions of $\mathrm{Na}^{+}$DNA. Proc. Natl. Acad. Sci. USA, 1986, 83 (2), 342-346.

DOI: $10.1073 /$ pnas.83.2.342.

4. Yevdokimov Yu.M., Skuridin S.G., Salyanov V.I. The liquid-crystalline phases of double-stranded nucleic acids in vitro and in vivo. Liquid Cryst., 1988, 3 (11), 1443-1459. DOI: $10.1080 / 02678298808086687$.

5. Livolant F. Ordered phases of DNA in vivo and in vitro. Physica A, 1991, 176 (1), 117-137.

DOI: $10.1016 / 0378-4371(91) 90436-G$.

6. Yevdokimov Yu.M., Salyanov V.I., Semenov S.V., Skuridin S.G. DNA Liquid-Crystalline Dispersions and Nanoconstructions. Boca Raton - London - New York: CRC Press (Taylor \& Francis Group), 2011. 258 p.

7. Livolant F. Cholesteric liquid crystalline phases given by three helical biological polymers: DNA, PBLG and xantan. A comparative analysis of their textures. J. Phys. (France), 1986, 47 (9), 1605-1616. DOI: $10.1051 /$ jphys:019860047090160500.

8. Livolant F., Bouligand Y. Liquid crystalline phases given by helical biological polymers (DNA, PBLG and xanthan). Columnar textures. J. Phys. France, 1986, 47 (10), 1813-1827.

DOI: $10.1051 /$ jphys:0198600470100181300.

9. Livolant F., Levelut A.M., Doucet J., Benoit J.P. The highly concentrated liquid-crystalline phase of DNA is columnar hexagonal. Nature, 1989, 339 (6227), 724726. DOI: $10.1038 / 339724 \mathrm{a} 02739717$.

10. Rill R.L., Strzelecka T.E., Davidson M.W., van Winkle D.H. Ordered phases in concentrated DNA solutions. Phys. A, 1991, 176 (1), 87-116.

DOI: $10.1016 / 0378-4371(91) 90435-F$.

11. Livolant F., Leforestier A. Condensed phases of DNA: structures and phase transitions. Prog. Polym. Sci., 1996, 21 (6), 1115-1164.

DOI: $10.1016 / \mathrm{S} 0079-6700(96) 00016-0$.

12. Kassapidou K., Jesse W., van Dijk J.F., van der Maarel J.R. Liquid crystal formation in DNA fragment solutions. Biopolymers, 1998, 46 (1), 31-37.

DOI:10.1002/(SICI)1097-282(199807)46:1<31::AIDBIP3>3.0.CO;2-Z. 
13. Lerman L.S. A transition to a compact form of DNA in polymer solutions. Proc. Natl. Acad. Sci. USA, 1971, 68 (8), 1886-1890. DOI:10.1073/pnas.68.8.1886.

14. Evdokimov Yu.M., Platonov A.L., Tikhonenko A.S., Varshavsky Ya.M. A compact form of double-stranded DNA in solution. FEBS Lett., 1972, 23 (2), 180-184. DOI: $10.1016 / 0014-5793(72) 80335-1$

15. Yevdokimov Yu.M., Skuridin S.G., Lortkipanidze G.B. Liquid-crystalline dispersions of nucleic acids. Liquid Cryst., 1992, 12 (1), 1-16.

DOI: $10.1080 / 02678299208029034$.

16. Goldar A., Thomson H., Seddon J.M. Structure of DNA cholesteric spherulitic droplet dispersions. J. Phys.: Condens. Matter, 2007, 20 (3), 9 p. DOI:10.1088/0953-8984/20/03/035102.

17. Biswas N., Ichikawa M., Datta A., Sato Y.T., Yanagisawa M., Yoshikawa K. Phase separation in crowded micro-spheroids: DNA-PEG system. Chem. Phys. Lett., 2012, 539-540, 157-162.

DOI:10.1016/j.cplett.2012.05.033.

18. Hoang T.X., Giacometti A., Podgornik R., Nguyen N.T., Banavar J.R., Maritan A. From toroidal to rod-like condensates of semiflexible polymers. J. Chem. Phys., 2014, 140 (6), 064902. DOI:10.1063/1.4863996.

19. Yevdokimov Yu.M., Skuridin S.G., Salyanov V.I., Bykov V.A., Palumbo M. Biotechnology. V. 4: Applied Synthetic Biology / Ed. by V. Singh. Houston : Studium Press LLC, 2014, 327-380.

20. Yevdokimov Yu.M., Salyanov V.I., Savateev M.N., Dubinskaya V.A., Skuridin S.G. Analysis of "solid" nanocostructs formed of liquid-crystalline DNA dispersion particles by the method of atomic force microscopy. Technologies of Living Systems, 2013, 10, 20-27. (in Russ.).

21. Stanley C.B., Hong H., Strey H.H. DNA cholesteric pitch as a Function of density and ionic strength. Biophys. J., 2005, 89 (4), 2552-2557. DOI:10.1529/biophysj.105.064550.

22. Yevdokimov Yu.M., Salyanov V.I., Skuridin S.G., Semenov C.V., Kompanets O.N. The CD Spectra of Double-Stranded DNA Liquid Crystalline Dispersions. New York : Nova Science Publishers, 2011, 103 p.

23. Semenov S.V., Yevdokimov Yu.M. Circular dichroism of DNA liquid-crystalline dispersion particles. Biophysics, 2015, 60 (2), 188-196. DOI: $10.1134 /$ S0006350915020177.

24. Bloomfield V.A., Crothers D.M., Tinoko I. Physical Chemistry of Nucleic Acids. New York : Harper \& Row, 1974, $517 \mathrm{p}$.

25. Saeva F.D., Wysocki J.J. Induced circular dichroism in cholesteric liquid crystals. J. Am. Chem. Soc., 1971, 93 (22), 5928-5929. DOI:10.1021/ja00751a075.

26. Sackman E., Voss J. Circular dichroism of helically arranged molecules in cholesteric phases. Chem. Phys. Lett., 1972, 14 (4), 528-532.
DOI:10.1016/0009-2614(72)80256-2.

27. de Vries H. Rotatory power and other optical properties of certain liquid crystals. Acta Cryst., 1951, 4(3), 219-226. DOI:10.1107/S0365110X51000751.

28. Mauguin C. Sur les cristaux liquids de Lehman. Bull. Soc. Franc. de Minéralogie, 1911, 34, 71-117.

29. Nordén B. Application of linear dichroism spectroscopy. Appl. Spectrosc. Rev., 1978, 14 (2), 157-248. DOI: 10.1080/05704927808060393.

30. Belyakov V.A., Orlov V.P., Semenov S.V., Skuridin S.G., Yevdokimov Yu.M. Comparison of calculated and observed CD spectra of liquid crystalline dispersions formed from double-stranded DNA and from DNA complexes with coloured compounds. Liquid Cryst., 1996, 20 (6), 777-784. DOI: $10.1080 / 02678299608033172$.

31. Yevdokimov Yu.M., Skuridin S.G., Salyanov V.I., Kats E.I. Hexagonal $\rightarrow$ cholesteric phase transition of DNA molecules in liquid-crystalline dispersion particles. Dokl. Phys. Chem., 2016, 467 (2), 53-55. DOI: $10.1134 / \mathrm{S} 0012501616040035$.

32. Yevdokimov Yu.M., Skuridin S.G., Semenov S.V., Dadinova L.A., Salyanov V.I., Kats, E.I. Re-entrant cholesteric phase in DNA liquid-crystalline dispersion particles. J. Biol. Phys., 2017, 43 (1), 45-68. DOI: $10.1007 / \mathrm{s} 10867-016-9433-4$.

33. Yevdokimov Yu.M., Skuridin S.G., Salyanov V.I., Semenov S.V., Shtykova E.V. Dadinova L.A., Kompanets O.N., Kats E.I. The re-entrant cholesteric phase of DNA. Optics Spectr., 2017, 123 (1), 56-69. DOI: $10.1134 / \mathrm{S} 0030400 \mathrm{X} 17070062$.

34. Gautier A., Michel-Salamin L., Tosi-Couture E., McDowall A.W., Dubochet J. Electron microscopy of the chromosomes of dinoflagellates in situ: confirmation of Bouligand's liquid crystal hypothesis. J. Ultrastruct. Mol. Struct. Res., 1986, 97 (1-3), 1030. DOI: 10.1016/S0889-1605(86)80003-9.

35. Tinoko I., Bustamante C., Maestre M.F. The optical activity of nucleic acids and their aggregates. Annu. Rev. Biophys. Bioeng., 1980, 9, 107-141.

DOI: 10.1146 /annurev.bb.09.060180.000543.

36. Grasso D., Fasone S., La Rosa C., Salyanov V. A calorimetric study of the different thermal behaviour of DNA in the isotropic and liquid-crystalline states. Liquid Cryst., 1991, 9 (2), 299-305. DOI: $10.1080 / 02678299108035507$.

37. Evdokimov Yu.M., Pyatigorskaya T.L., Belozerskaya N.A., Varshavsky Ya.M., Becker M., Zirver D. DNA compact form in solution. XI. Melting of the DNA compact state, formed in water-salt solutions, containing poly(ethylene glycol). Molecular Biology, 1977, 11 (3), 507-515. (in Russ.). PMID:752789.

38. Grasso D., Gabriele-Campisi R., La Rosa C. Microcalorimetric measurements of thermal denaturation and renaturation processes of salmon 
sperm DNA in gel and liquid crystalline phases. Thermochim. Acta, 1992, 199, 239-245.

DOI: $10.1016 / 0040-6031(92) 80268-2$.

39. Sonin A.S. Introduction to the Physics of Liquid Crystals. Moscow : Nauka, 1983, 320 p. (in Russ.)

40. Sundaresan N., Thomas T., Thomas T.J., Pillai C.K. Lithium ion induced stabilization of the liquid crystalline DNA. Macromol. Biosci., 2006, 6 (1), 2732. DOI: $10.1002 / \mathrm{mabi} .200500145$.

41. Kornyshev A., Leikin S., Malinin S.V. Chiral electrostatic interaction and cholesteric liquid crystals of DNA. Eur. Phys. J. E, 2002, 7 (1), 83-93.

DOI: $10.1140 /$ epje/i200101159.

42. Rau D.C., Lee B., Parsegian V.A. Measurement of the repulsive force between poly-electrolyte molecules in ionic solution-hydration forces between parallel DNA double helices. Proc. Natl. Acad. Sci. USA, 1984, 81 (9), 2621-2625. DOI: 10.1073/pnas.81.9.2621.

43. Salyanov V.I., Pogrebnyak V.G., Skuridin S.G., Lortkipanidze G.B., Chidzhavadze Z.G., Toryanik A.I., Yevdokimov Yu.M. On the relation between the molecular organization of the solution of poly(ethyleneglycol) - water and the compactization of thedouble-stranded DNA molecules. Molecular Biology, 1978, 12 (3), 367-375. (in Russ.).

44. Grossberg A.Yu., Erukhimovich Ya.I., Shakhnovich E.I. On the theory of $\psi$-condensation. Biopolymers, 1982, 21 (12), 2413-2432. DOI: 10.1002/bip.360211207.

45. Mariani P., Saturni L. Measurement of intercolumnar forces between parallel guanosine four-stranded helices. Biophys. J., 1996, 70 (6), 2867-2874.

DOI: $10.1016 / \mathrm{S} 0006-3495(96) 79856-9$.

46. Strey H.H., Parsegian V.A., Podgornik R. Equation of state for DNA liquid crystals: fluctuation enhanced electrostatic double layer repulsion. Phys. Rev. Lett., 1997, 78 (5), 895-898.

DOI:10.1103/PhysRevLett.78.895.

47. Leonard M., Hong H., Easwar N., Strey H.H. Soft matter under osmotic stress. Polymer, 2001, 42 (13), 5823-5827. DOI: 10.1016/S0032-3861(0)00903-4.

48. Ubbink J., Odijk T. Polymer-induced and salt-induced toroids of hexagonal DNA. Biophys. J., 1995, 68 (1), 54-61. DOI: $10.1016 / \mathrm{S} 0006-3495(95) 80158-\mathrm{X}$.

49. de Vries R. Flexible polymer-induced condensation and bundle formation of DNA and F-actin filaments. Biophys. J., 2001, 80 (3), 1186-1194.

DOI: $10.1016 / \mathrm{S} 0006-3495(01) 76095-\mathrm{X}$.

50. Kolli H.B., Frezza E., Cinacchi G., Ferrarini A., Giacometti A., Hudson T.S. From rods to helices: evidence of a screw-like nematic phase. J. Chem. Phys., 2014, 140 (8), 081101. DOI: 10.1063/1.4866808.

51. Wu L., Sun H. Cholesteric ordering predicted using a coarse-grained polymeric model with helical interactions. Soft Matter, 2018, 14 (3), 344-353.
DOI: $10.1039 / \mathrm{c} 7 \mathrm{sm} 02077 \mathrm{e}$.

52. Tortora M.M.C., Doye J.P.K. Introducing particle flexibility into a density functional description of nematics and cholesterics. Soft Condensed Matter, 2018, 1-16. ArXiv: 1801.10601[cond-mat.soft].

53. Hoang T.X., Giacometti A., Podgornik R., Nguyen N.T., Banavar J.R., Maritan A. From toroidal to rod-like condensates of semiflexible polymers. J. Chem. Phys., 2014, 140 (6), 064902. DOI: 10.1063/1.4863996.

54. Burlyn E.M., Kaufman M.R. The osmotic potential of polyethylene glycol 6000. Plant. Physiol., 1973, 51 (5), 914-916. DOI: $10.1104 /$ pp.51.5.914.

55. Burlyn E.M. Evaluation of the water potentials of solutions of polyethylene glycol 8000 both in the absence and presence of other solutes. Plant Physiol., 1983, 72 (1), 66-70. DOI: 10.1104/pp.72.1.66.

56. Harris A., Kamien R.D., Lubensky T.C. Microscopic origin of cholesteric pitch. Phys. Rev. Lett., 1997, 78 (8), 1476-1479. DOI: 10.1103/PhysRevLett.78.1476.

57. Kornyshev A.A., Lee D.J., Leikin S., Wynveen A., Zimmerman S.B. Direct observation of azimuthal correlations between DNA in hydrated aggregates. Phys. Rev. Lett., 2005, 95 (14), 148102-148104.

DOI: $10.1103 /$ PhysRevLett.95.148102.

58. Strey H.H., Wang J., Podgornik R., Rupprecht A., Yu L., Parsegian V.A., Sirota E.B. Refusing to twist: demonstration of a line hexatic phase in DNA liquid crystals. Phys. Rev. Lett., 2000, 84 (14), 3105-3108. DOI: $10.1103 /$ PhysRevLett.84.3105.

59. Hud N.V., Vilfan I.D. Toroidal DNA condensates: unraveling the fine structure and the role of nucleation in determining size. Annu. Rev. Biophys. Biomol. Struct., 2005, 34 (1), 295-318.

DOI: 10.1146 /annurev.biophys.34.040204.144500.

60. Vilfan I.D., Conwell C.C., Sarkar T, Hud N.V. Time study of DNA condensate morphology: implications regarding the nucleation, growth, and equilibrium populations of toroids and rods. Biochemistry, 2006, 45 (26), 8174-8183. DOI: 10.1021/bi060396c.

61. Yasar S., Podgornik R., Valle-Orero J. Johnson M.R., Parsegian V.A. Continuity of states between the cholesteric $\rightarrow$ line hexatic transition and the condensation transition in DNA solutions. Sci. Rep., 2014, 4, article number $6877.10 \mathrm{p}$.

DOI: $10.1038 /$ srep06877.

62. Rill R.L., Livolant F., Aldrich H.C., Davidson M.W. Electron microscopy of liquid crystalline DNA: direct evidence for cholesteric-like organization of DNA in dinoflagellate chromosomes. Chromosoma, 1989, 98 (4), 280-286. DOI: 10.1007/BF00327314.

63. Bouligand Y., Norris V. Chromosome separation and segregation in dinoflagellates and bacteria may depend on liquid crystalline states. Biochimie, 2001, 83 (2), 187-192. DOI:10.1016/S0300-9084(00)01211-6. 
64. Sartori B.N., Senn A., Leforestier A., Livolant F., Dubochet J. DNA in human and stallion spermatozoa forms local hexagonal packing with twist and many defects. J. Struct. Biol., 2001, 134 (1), 76-81. DOI:10.1006/jsbi.2001.4365.

65. Chow M.H., Yan K.T.H., Bennett M.J., Wong J.T.Y. Birefringence and DNA condensation of liquid crystalline chromosomes. Eukaryot. Cell, 2010, 9 (10), 1577-1587. DOI: 10.1128/EC.00026-10.

66. Evgen'ev M.B., Garbuz D.G., Zatsepina O.G. Heat Shock Proteins and Whole Body Adaptation to Extreme Environments. Dordrecht : Springer Science + Business Media Dordrecht, 2014, 218 p. DOI: $10.1007 / 978-94-017-9235-6$.
67. Belyakov V.A., Sonin A.S. Optics of Cholesteric Liquid Crystals. Moscow : Nauka, 1982, 360 p. (in Russ.).

68. Belyakov V.A., Demikhov E.I., Dmitrienko V.E., Dolganov V.K. Optical activity, transmission spectra, and structure of blue phases of liquid crystals. Sov. Phys. JETP, 1985, 62 (6), 1173-1182.

Поступила в редакичию 17.04.2018 2. Received 17 April 2018 